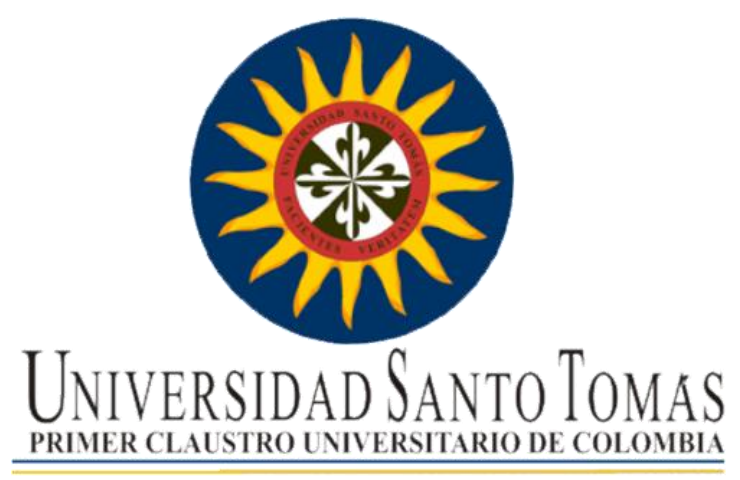

\title{
LA EFECTIVIDAD DE LOS DERECHOS DE LOS CONSUMIDORES QUE ADQUIEREN UN CONTRATO DE SEGURO DE VIDA - GRUPO DEUDORES
}

\author{
Autor : \\ Javier Fernando Mera Muñoz \\ Trabajo de investigación presentado como requisito parcial para optar por el título de: \\ Magister en Derecho Contractual Público y Privado
}

Directora: Ángela María Medina Panqueva

Facultad de Derecho

Maestría en Derecho Contractual Público y Privado

Bogotá, D.C. Colombia, Julio de 2018 
Introducción

1. CAPÍTULO I EL CONTRATO DE SEGURO DE VIDA GRUPO DEUDORES. EVOLUCIÓN TEÓRICA, NORMATIVA Y JURISPRUDENCIAL DE LA CORTE CONSTITUCIONAL

Resumen

$\begin{array}{ll}\text { 1.1. Introducción } & 10\end{array}$

1.2. El contrato de seguro de vida grupo deudores 11

1.2.1. Elementos teórico-conceptuales del contrato de seguro 11

1.2.2. Características del contrato de seguro de vida grupo deudores 28

1.3. Marco normativo que rige el contrato de seguro de vida grupo deudores

1.4. Análisis jurisprudencial sobre los contratos de seguro de vida grupo deudores

1.5. Estudio de la aplicación del contrato de seguro de vida grupo deudores en tres compañías aseguradoras

1.6. Conclusiones

1.7. Referencias

2. CAPÍTULO II CARACTERIZACIÓN DE LOS DERECHOS DEL CONSUMIDOR FINANCIERO EN EL MARCO DEL CONTRATO DE SEGURO VIDA GRUPO DEUDORES EN COLOMBIA

Resumen 
2.1. Introducción

2.2. Consumidor financiero (definición, tipos, derechos, obligaciones) en el marco de los contratos de seguro en Colombia $\quad 64$

$\begin{array}{lll}\text { 2.2.1. Sistema financiero } & 64\end{array}$

2.2.2. Definición de consumidor financiero $\quad 67$

2.2.3. Marco legal del consumidor financiero $\quad 69$

$\begin{array}{lll}\text { 2.2.4. Derechos del consumidor financiero } & 75\end{array}$

2.2.5. Obligaciones del consumidor financiero 83

2.3. El asegurado como sujeto de las relaciones de consumo en los contratos de $\begin{array}{ll}\text { seguros en Colombia } & 86\end{array}$

2.4. Herramientas jurídicas a implementar para fortalecer los derechos del consumidor financiero en los contratos de seguro de vida grupo deudores 92

2.5. Mecanismos específicos para ser implementados por las entidades financieras al momento de hacer entrega de la póliza de seguro de vida grupo deudores. $\quad 94$

2.6. Conclusiones 96

$\begin{array}{ll}\text { 2.7. } & \text { Referencias }\end{array}$ 


\section{Introducción}

El trabajo de investigación que se presenta a continuación tiene como objetivo general determinar, desde una perspectiva crítica y de forma propositiva, si en Colombia bajo el nuevo Estatuto del Consumidor y normas concordantes, los contratos de seguro de vida grupo deudores garantizan los derechos del consumidor financiero, particularmente el derecho a la información de los tomadores y deudores.

Este objetivo obedece al interés por evaluar, desde el ámbito jurídico (normas, doctrina y jurisprudencia) cuál ha sido la caracterización y proceder del contrato de seguro, particularmente del seguro de vida grupo deudores, en el marco de la nueva legislación relativa al consumidor financiero. Para ello se requiere entender previamente, tal como lo sostiene la Corte Constitucional en sentencia T-832 de 2010, que en la relación contractual entre la compañía aseguradora y el tomador y/o asegurado, existe una posición de dominio de la primera, para lo cual el Estado, fija herramientas jurídicas para la protección y amparo de los segundos.

Valga decir igualmente que este acuerdo, entre una persona que busca asegurarse frente a la ocurrencia de un riesgo, y la persona que se obliga a resarcirlo en caso de que ocurra, a cambio de una contraprestación económica, se denominó contrato de seguro. Una vez el contrato de seguro apareció en el ámbito jurídico, se establecieron las partes que en el intervienen y las obligaciones que emanan de cada uno, y mutó en varias clases, en procura de asegurar varios riesgos, de ahí que en un esfuerzo por clasificarlos se los haya organizado en dos grandes grupos, los seguros de daños patrimoniales y los seguros de vida. 
El porqué de la anterior clasificación radicó en su mayoría, teniendo en cuenta que todo ser humano tiene la necesidad de proteger su patrimonio, protegerse a sí mismo y proteger su núcleo familiar. En un mundo globalizado e industrializado como el actual, son muchos los emporios económicos que brindan sus servicios como aseguradoras, a través de sus corredores, con lo cual garantizan una mayor presencia en el mercado, y por lo tanto, que más personas adquieran sus servicios (Peñalosa, 2015).

No obstante lo anterior, estas compañías empezaron a cometer ciertos abusos con los consumidores, ya sean durante la adquisición del seguro, su ejecución, o una vez ocurrido el siniestro, para cancelar el daño. Esto, por cuanto al tener una posición dominante en el mercado que, conforme lo afirma la Corte Constitucional mediante sentencia T-282 de 2016, corresponde a aquella relación de asimetría entre la aseguradora y el usuario o cliente, pues al estar aquella en un nivel de superioridad respecto al tomador, imponen sus condiciones, las cuales en la mayoría de las veces se convierten en abusivas o lo que comúnmente se conoce como "leoninas". En ese sentido, la posición dominante contractual corresponde a la aceptación tácita que debe hacer el usuario de todas y cada una de las estipulaciones contempladas en dichos contratos por parte de la entidad aseguradora.

Conforme a la problemática presentada, la pregunta de investigación a resolver fue: ¿si el Estatuto del Consumidor y las demás normas concordantes están garantizando efectivamente los precitados derechos, específicamente el deber de información, que deben suministrar las entidades financieras y las compañías aseguradoras?

A partir de este eje problemático, los objetivos específicos planteados para este estudio fueron los siguientes: analizar el alcance teórico de consumidor financiero y el deber de información, desde su definición, tipos, derechos y obligaciones, como parte integral del 
contrato de seguro en Colombia, particularmente del seguro de vida grupo deudores; establecer desde una perspectiva integral y sistemática al asegurador como sujeto de las relaciones de consumo en los contratos de seguros en Colombia, desde su alcance, derechos y obligaciones; identificar la función que cumple en el mercado el contrato de seguro, desde una perspectiva histórica del sistema jurídico propio de la Constitución Política de 1991; identificar las principales características del contrato de seguro de vida grupo deudores, de conformidad con el estudio de compañías aseguradoras del país, la normatividad que lo rige en el ámbito jurídico nacional y la supervisión que sobre éste realizan los entes de control.

Otros objetivos específicos a desarrollar fueron: identificar, según la jurisprudencia y las decisiones de la Superintendencia de Industria y Comercio, los casos más representativos en los en los cuales se ha presentado una vulneración de los consumidores que ha adquirido un contrato de seguro de vida deudores, teniendo en cuenta aquellos casos en los cuales las compañías aseguradoras al momento de resarcir el perjuicio se abstuvieron de realizar el pago y; por último, realizar una reflexión y/o crítica sobre cómo las autoridades administrativas y el poder legislativo pueden procurar por elaborar herramientas jurídicas que permitan que el derecho que tienen los consumidores, sobre todo el deber de información, el cual está regido por unos principios, se materialice y se efectivice respecto a la relación de consumo que existe entre el tomador y/o asegurado de un seguro de vida - grupo deudores y una compañía aseguradora.

Sobre estos objetivos, la hipótesis a desarrollar el trabajo es que los derechos de los consumidores, particularmente el deber de información, en este caso tomadores y asegurados de un seguro de vida grupo deudores, se ven afectados por la falta regulación en el Estatuto del Consumidor y normas concomitantes en lo que tiene que ver inicialmente con la posición 
de dominio de las aseguradoras y con el derecho a una información completa, veraz, transparente, oportuna, verificable, comprensible, precisa e idónea que debe brindar la compañía aseguradora y la entidad bancaria al momento de ofrecer la póliza para el otorgamiento de un crédito.

En ese sentido, la metodología que se utilizó el desarrollo y ejecución del presente proyecto parte en principio de que el presente es un artículo de reflexión con estrategias de investigación de análisis de comentario y estudio descriptivo de casos. Asimismo, es el método deductivo, pues se partió de lo general, particularmente de los elementos teóricoconceptuales, así como de la normatividad general, para llegar a los elementos particulares, representados en los casos asumidos por la Corte Constitucional, para identificar qué derechos de los consumidores financieros han sido vulnerados y la conducta establecida por las entidades aseguradoras. Se hizo una extenuante revisión documental que aborde los temas de los derechos de los consumidores financieros y los contratos de seguro de vida - grupo deudores.

La verificación documental se hizo mediante una revisión bibliográfica de la normatividad, la doctrina y la jurisprudencia, toda vez que para dar respuesta a la pregunta problema, fue necesario localizar y buscar la información que aborde los temas relacionados con el derecho que tienen los consumidores financieros, así como el relacionado con los contratos de seguros, específicamente los de vida - grupo deudores.

Con fundamento en esta metodología y en los objetivos definidos, en el primer capítulo se abordó la caracterización del contrato de seguro de vida grupo deudores, en el que se tuvieron en cuenta los elementos teórico-conceptuales del contrato de seguro, el marco normativo que rige el contrato de seguro y un análisis de la línea jurisprudencial de la Corte 
Constitucional sobre el seguro de vida grupo deudores. Finalmente, se hizo un estudio sobre la caracterización a tres empresas aseguradoras sobre el tratamiento, requisitos, cobertura y exclusiones el seguro de vida grupo deudores.

En el segundo capítulo se aborda de forma integral el análisis de los derechos del consumidor financiero, en especial del derecho a la información, en el marco del contrato de seguro de vida grupo deudores, partiendo de los elementos teórico-conceptuales de sistema financiero, consumidor financiero, para continuar ulteriormente con el marco legal de la institución del consumidor financiero, sus derechos y obligaciones. Posteriormente, se analiza la relación que hay entre el asegurado, como sujeto de relaciones de consumo en los contratos de seguro, para terminar con las herramientas jurídicas a implementar para fortalecer los derechos del consumidor financiero en los contratos de seguro de vida grupo deudores. 


\section{CAPÍTULO I EL CONTRATO DE SEGURO DE VIDA GRUPO DEUDORES. EVOLUCIÓN TEÓRICA, NORMATIVA Y JURISPRUDENCIAL DE LA CORTE CONSTITUCIONAL}

\section{Resumen}

El contrato de seguro de vida grupo deudores se erige como uno de los negocios jurídicos generadores de controversia, partiendo sobre todo del hecho de la posición dominante que representan las entidades financieras, en especial las compañías aseguradoras, las cuales se reflejan no sólo en el poder que tiene en el mercado, sino que se materializa en el mismo contrato de seguro, tal como lo evidencia la misma Corte Constitucional mediante sentencia T-268 de 2013. Debido a ello, en el presente capítulo se hace un análisis teórico y jurídico (ley, doctrina y jurisprudencia) sobre los efectos que tiene este tipo de contratos en los deudores, quienes se convierten en sujetos de protección constitucional por parte de la Corte Constitucional, ante la evidente conculcación de derechos fundamentales.

\footnotetext{
Abstract

The contract of life insurance debtors group stands as one of legal businesses generating controversy, especially from the fact of the dominant position which represent financial institutions, especially the insurance companies, which are they reflect not only in power that has in the market, but is embodied in the same insurance contract, as evidenced by the Constitutional Court judgment T-268 from 2013. As a result, in this chapter a theoretical and legal analysis (law, doctrine and jurisprudence) is made on the effects that has this type of contracts in the debtors, who become subjects of constitutional protection by the Court Constitutional, to the evident violation of fundamental rights.
} 


\subsection{Introducción}

Los contratos de seguro, en particular los contratos de seguro de vida grupo deudores, ocupan un lugar especial en el mundo jurídico, dado no sólo por la magnitud de los negocios jurídicos, sino por las implicaciones constitucionales que tiene para los deudores, en esa relación contractual con las entidades crediticias (bancos) y las aseguradoras. Bien recuerda Ordóñez (2014) que uno de los problemas más álgidos en los seguros de vida, es que se han llevado a cabo reformas legislativas que no han contribuido a allanar el camino y a contrario sensu se han revelado como muy apresuradas y superficiales.

Para dar respuesta a dicha caracterización del seguro de vida grupo deudores, en un primer momento se establecen los elementos esenciales de este tipo de contratos, partiendo de las definiciones generales del contrato de seguro, para culminar con las características del contrato objeto de estudio. Enseguida, se identifica el marco normativo que rige dichos contratos, tomando especial atención en los mecanismos de supervisión y control establecido por la Superintendencia Financiera de Colombia.

Una vez clarificado este marco normativo, se procede en seguida con el análisis jurisprudencial de la Corte Constitucional, tomando en cuenta que la importancia está dada en identificar la línea jurisprudencial establecida por esta Corte para salvaguardar los derechos del consumidor financiero, en particular del deudor, ya que este se encuentra sometido a las estipulaciones del contrato, pero también de la posición de dominio de las entidades financieras.

Dicho análisis deja como colofón el estudio sobre los criterios, alcance y cobertura de los seguros de vida grupo deudores en tres compañías aseguradoras, identificando qué 
elementos coadyuvan a la protección del consumidor financiero y cuáles se convierten en barreras.

\subsection{El contrato de seguro de vida grupo deudores}

En principio, Arias y Navia (2015) señalan cómo el seguro surge de la necesidad de prevenir posibles consecuencias frente a un riesgo, que si el mismo ocurre se genera el llamado siniestro, el cual generaría un amparo o derecho a indemnización para el tomador. En ese mismo sentido se plantea por doctrinante que la "conjunción de la necesidad individual y de la sociedad de protegerse contra la ocurrencia de riesgos y de solventar su efecto económico dañino crea la conciencia de la necesidad de amparar los riesgos mediante el contrato de seguro" (Becerra, 2014, p. 11).

Bajo este entendido, en el presente capítulo se abordarán inicialmente los elementos teórico-conceptuales del seguro de vida, particularmente del seguro de vida grupo deudores, para avanzar ulteriormente con las características de este tipo de contrato. Enseguida se asume el estudio del marco jurídico, incluyendo el análisis normativo vigente, así como los aportes de la jurisprudencia al respecto. La comprensión de estos elementos conlleva enseguida al estudio sobre la forma como tres compañías aseguradoras abordan el contrato de seguro de vida grupo deudores, logrando con ello tener una visión sistemática sobre la forma como se caracteriza.

\subsubsection{Elementos teórico-conceptuales del contrato de seguro}

Establecer una noción clara y diáfana sobre el contrato de seguro, criterio previo para la comprensión del contrato del seguro de vida grupo deudores, es una tarea que todavía no tiene consenso. Aun así, un primer acercamiento Becerra (2014) el derecho de seguros es 
aquél comprendido por el “conjunto de normas jurídica que regulan la actividad económica aseguradora, como expresión de la actividad socioeconómica”.

De acuerdo con lo expresado, esta noción es muy limitada, pues excluye otros elementos sustanciales del derecho de seguros como es la jurisprudencia y la doctrina, aspectos esenciales que no se pueden dejar al margen por el nivel de incidencia que tiene en la toma de decisiones del operador judicial (Plaza, Cadena, Gutiérrez y Acero, 2006).

También se encuentra la definición dada por Narváez (2014) quien plantea que el contrato de seguro tiene dos connotaciones, una técnica y otra jurídica. Para la primera, citando Manes, subraya que el seguro es "la protección mutua de numerosas existencias económicas, análogamente amenazadas, ante necesidades fortuitas y tasable de dinero” (p. 95) de ahí que proponga este autor establecer o identificar dos tipos de nociones; una técnica y otra jurídica. Desde el punto de vista técnico, subraya:

La operación de seguros consiste en una mutualidad de la que forman parte personas expuestas a riesgos homogéneos y quienes contribuyen económicamente al fondo común a cambio del resarcimiento de los daños sufridos por la ocurrencia de uno o algunos de tales riesgos o ante la eventualidad de un desembolso (Narváez, 2014, p. 96).

Como bien se observa, esta definición técnica tiene los elementos básicos de un contrato de seguro como son el riesgo y el siniestro. El primero debe estar soportado o validado con la cancelación de una prima, en tanto que el segundo se manifiesta cuando se producen unos daños previamente estipulados en el contrato de seguro (Peña, Álvarez y Busto, 2011). De igual manera Mejía (2017) dice frente al riesgo lo siguiente: 
Cualquier empresa, del tipo que sea y donde esté, siempre estará rodeada de diferentes tipos de amenazas que, al materializarse en cualquier momento, pueden impactar gravemente las finanzas de la misma. El mundo actual, con una economía globalizada, en un mercado abierto y altamente competido, con grandes avances tecnológicos y condiciones sociopolíticas complejas, se convierte en un escenario donde las empresas son altamente vulnerables y por ello, hoy más que nunca, es vital un manejo adecuado y técnico del riesgo (Mejía, 2017, p. 11).

Como noción jurídica, se expresa que el contrato de seguro corresponde al compromiso de una de las partes, el asegurador, que se obliga a asumir un riesgo previamente acordado, a cambio de un precio o prima pactado con el asegurado, que en caso de materializarse en un siniestro, tiene el deber de indemnizar la suma que previamente se hubiere convenido (Medina y Reina, 2004). En consonancia con ello, el seguro tiene una connotación similar:

El seguro es una técnica de transferencia de riesgos, de sucesos futuros e inciertos que no dependen de la voluntad del tomador, asegurado beneficiario, o bien como hechos o circunstancias de naturaleza aleatoria, que además, exige la presencia de una pluralidad de personas para que opere el principio de mutualidad o de solidaridad y a la ley matemática de los grandes números (Narváez, 2014, p. 96).

De otro lado, en cuanto a intervinientes, valga señalar que en el plano estrictamente contractual, en el seguro se encuentran aquellos que intervienen directamente en el contrato como son el asegurador y el tomador y, secundariamente, al asegurado o beneficiario (Peláez, 2004, Cardona, 2013, Mosquera, 2010). 
En cuanto al asegurador, se dice que este corresponde a la persona jurídica que tiene como principal característica que se exige a reconocer a otra persona del daño que puede producir la realización de indiscutibles riesgos a que están expuestos tanto bienes o servicios, la persona o el patrimonio (Menchú, 2012). Esto significa que es la entidad que asume los riesgos conforme a las estipulaciones debidamente expresadas en la póliza, pero recordando también bajo la vigilancia, inspección y control por parte del Estado, luego debe someterse a cumplir con los criterios legales, so pena de verse sometido a sanciones por el incumplimiento de algunas de estas normas.

Por consiguiente, los únicos detonantes para la afectación de la póliza son la muerte o la incapacidad total y permanente, que sin otra consideración determinan la obligación de la aseguradora de cancelar el valor asegurado, que no es otro que el saldo insoluto del crédito, y el derecho correlativo de la entidad financiera de formular reclamación pretendiendo el pago de dicha obligación (Ramírez, 2015, p. 113).

Asimismo, el tomador es la persona, natural o jurídica, que celebra un contrato de seguro, bien por cuenta propia o ajena, para el beneficio propio o de un tercero ajeno al contrato, con el objeto de transferir un riesgo al asegurador (Marcano, 2014).

Por último, está el asegurado o beneficiario, que es la persona a la que el seguro cataloga como beneficiaria de la indemnización. Narváez (2014) precisa que en el caso de los seguros reales, el beneficiario y el asegurado coinciden y es en ellos en quienes radican las consecuencias del posible daño ocasionado. No sucede lo mismo con los seguros de fianza o de vida, en el que el beneficiario y asegurado serán "personas diferentes en razón a la naturaleza y características de los amparaos que estas pólizas confieren” (p. 113). 
Se subraya igualmente que tanto asegurado o beneficiario son las personas que están llamadas a percibir la compensación que surge del contrato de seguro, pero siempre y cuando, los hechos se encuentren previstos en el amparo, pero también que no deben concurrir factores que vayan a incidir en su validez o existencia (Agobian, 2008).

Becerra (2014) plantea que la teoría del seguro tiene su aspecto central en la idea del riesgo, como elemento causante de zozobra, de ahí que su fin no sea otro que brindar un amparo frente al riesgo objeto de seguro. Conforme a ello, se recalca que no existe una definición de contrato de seguro en la legislación colombiana, aun cuando se plantea que tiene unos elementos básicos, siendo, entre otros, que es un "acuerdo de voluntades, creador de obligaciones, de tipo consensual, bilateral, oneroso, aleatorio, de tracto sucesivo, principal, intuitu personae, de adhesión, y de buena fe" (p. 17).

A partir de estos elementos, se define el contrato de seguro como aquél en el que una de las partes, el asegurar "se compromete a asumir los riesgos que concreta el tomador o el beneficiario, y que pueden resultar afectados por la realización del siniestro, con cargo de compensar o resarcir el asegurar a quien sea beneficiario de la prestación amparada" (Becerra, 2014, p. 18).

Otra noción a tomar en cuenta es la de riesgo, que es definida inicialmente en el artículo 1054 del C.Co bajo los siguientes términos:

Denominase riesgo el suceso incierto que no depende exclusivamente de la voluntad del tomador, del asegurado o del beneficiario, y cuya realización da origen a la obligación del asegurador. Los hechos ciertos, salvo la muerte, y los físicamente imposibles, no constituyen riesgos y son, por lo tanto, extraños al contrato de seguro. 
Tampoco constituye riesgo la incertidumbre subjetiva respecto de determinado hecho que haya tenido o no cumplimiento (Código del Comercio, 1971, art. 1054).

En principio, se entendería el riesgo como la posibilidad de que determinado peligro genere un incidente con consecuencias que pueden ser estimadas. En el caso de que sea un riesgo asegurable, el mismo es puro, ya que existe la posibilidad de perder, pero no de ganar (Casallas, Martínez y Parra, 2006, p. 2). Una definición más precisa del riesgo en el contrato de seguro es la proveniente de Narváez (2014) en los siguientes términos:

El riesgo se identifica con la posibilidad de una desviación adversa respecto de un resultado deseado (...) puede definirse como un hecho futuro e incierto del cual se derivan consecuencias adversas para el asegurado y de cuyo acaecimiento pende la obligación de indemnizar radicada en cabeza del asegurador (Narváez, 2014, p. 118).

Esto significa que cuando se plantea un contrato de seguro, no se está ante la convicción de que determinado riesgo termine en siniestro, sino en que las circunstancias conlleven a que se presente un resultado contrario al que estaba siendo previsto en las cláusulas del contrato de seguro. En esa línea, se plantean dos aspectos especiales a tomar en cuenta con respecto al riesgo en los contratos de seguro; la incertidumbre y la imposibilidad (Aranda y Castillo, 2010).

La incertidumbre se plantea en dos sentidos, la objetiva y subjetiva. La primera tiene que ver la posibilidad de que se realice un acontecimiento futuro, pero que se desconozca la época en que tal se pueda presentar. No es lo mismo con la incertidumbre subjetiva, que sería entendida como un acontecimiento que ya se ha presentado, pero que los actores 
(contratantes) ignoran que ya haya ocurrido, es decir que el hecho ya existe, pero que los extremos del contrato lo desconocen en su totalidad (Murcia y Rodríguez, 2002).

Bajo ese entendido, Narváez (2014) recalca que el riesgo debe existir de manera objetiva, no sólo al momento de la celebración del contrato, sino durante su vigencia, pues puede tornarse inexistente a la luz del art. 898 del C. de Co., en el entendido que el riesgo es un elemento esencial del contrato de seguro: "Será inexistente el negocio jurídico cuando se haya celebrado sin las solemnidades sustanciales que la ley exija para su formación, en razón del acto o contrato y cuando falte alguno de sus elementos esenciales”.

De este modo, la imposibilidad corresponde, según Messineo, citado por Gadea (1986) se trataría de un impedimento "no superable por las fuerzas humanas o, caso de poderse superar, lo sería empleando una actividad ilícita, mediante el sacrificio de la integridad ética, o de algún otro atributo de la personalidad” (p. 70).

Se plantea también la existencia de dos tipos de riesgo, el jurídico y el técnico. En el ámbito jurídico se entiende como "un evento de naturaleza aleatoria, pero desde el punto de vista técnico, lo que interesa es medir la manera más o menos razonable, su grado de exposición, de tal forma que se persigue que el aporte económico o la prima pagada por el titular del riesgo a la mutualidad guarde cierta proporcionalidad” (Narváez, 2014, p. 97).

Con estas definiciones se identifican varios elementos esenciales como son el amparo del riesgo, que es otorgado por el asegurador, la existencia de una prima, que depende de los términos establecidos en el contrato y, eventualmente, la ocurrencia de un siniestro, el cual genera una obligación al asegurador de compensar o indemnizar al beneficiario o afectado con el siniestro (Becerra, 2011). 
De otro lado, para Gómez (2012) otra de las nociones que hace parte del contrato de seguro y que es esencial para los seguros de vida grupo deudores, es el relativo a la noción de saldo insoluto de la deuda. Para la Superintendencia Financiera dicho concepto se expresa de la siguiente manera:

Por saldo insoluto de la deuda, para efectos del presente numeral, se entenderá el capital no pagado, más los intereses corrientes calculados hasta la fecha de fallecimiento del asegurado. En el evento de mora en las obligaciones se comprenderán, además, los intereses moratorios y las primas del seguro de vida grupo deudores no cancelados por el deudor. Cuando el valor de la deuda a la cual se vincula el seguro se exprese en unidades de valor real UVR, la indemnización será calculada con base en la cantidad de las aludidas unidades adeudadas en la fecha del fallecimiento, liquidada a la cotización del día en el cual se efectúe el pago (...) en este tipo de pólizas pueden asegurarse los codeudores por la misma suma asegurada (Superintendencia Financiera, 2002, p. 26).

Además de estos elementos conceptuales básicos, se deben identificar los elementos esenciales del contrato de seguro, los cuales se encuentran establecidos en el art. 1045 del C. de Co., y que algunos ya se han venido ventilando a lo largo de este estudio, como son el interés asegurable, el riesgo asegurable, la prima o precio del seguro y la obligación condicional del asegurador.

El interés asegurable tiene que ver con "la posibilidad de afectación patrimonial como consecuencia de la ocurrencia de un riesgo (...) su desaparición sobreviniente torna el contrato en inexistente e invalida el derecho del asegurado a la indemnización prevista en la póliza” (Narváez, 2014, p. 117). 
El riesgo asegurable deviene del peligro o inseguridad que tiene el asegurado respecto a consecuencias futuras desfavorables de una actividad determinada que termine en un siniestro, es decir frente a potenciales peligros que pudieran lesionar o afectar el bien asegurado (Delgado, 2008).

Como limitantes del riesgo asegurable el art. 1055 del C. de Co., identifica el dolo, la culpa grave, los actos meramente potestativos del tomador, asegurado o beneficiario y, por último, el amparar contra sanciones de tipo penal o policivo. En la culpa grave se plantea que ello obedece al carácter aleatorio del riesgo como del propio contrato de seguro. Se precisa igualmente que para la culpa grave no sea asegurable, la misma debe ser manifiesta, burda y casi intencional, pues a contrario sensu, sí lo sería:

La Ley 45 de 1990 que subrogó el 1127 del estatuto mercantil, dio cabida a la asegurabilidad de la culpa grave bajo el seguro de responsabilidad civil, por cuanto restringirlo a hecho y circunstancia de carácter fortuito resultaba insuficiente en relación con el amplio espectro que (...) ha venido adquiriendo la responsabilidad civil (Narváez, 2014, p. 127).

En cuanto al dolo, vale decir que obedece a aquella falta intencional ocasionada por la mala fe, la cual no puede ser tomada como una fuente de derechos, generando que se suprima ese criterio aleatorio que proviene de los contratos de seguro, puesto que por parte del asegurado primó la intencionalidad de hacer o provocar el daño (Badillo, 2010).

Se destaca igualmente que en la estructuración de un contrato de seguro, se plantea la fase precontractual, que corresponde a la etapa en el que las partes identifican las ventajas y desventajas del amparo objeto de contrato, determinar si la protección estipulada es suficiente 
a las necesidades, determinar posibles amparos específicos comunes a la actividad que se va a tomar, establecer los derechos y obligaciones recíprocas, costos del seguro y evaluación o relación costo-beneficio para las partes (Díaz, 2008).

Importante subrayar que en la etapa precontractual, uno de los elementos básicos a tener en cuenta es el deber de información, que consiste en suministrar los datos más importantes que puedan generar alta incidencia en el negocio jurídico, pero sobre todo informar de buena fe, para evitar inducir a error a la contraparte (Miranda, 2016).

De manera genérica, el deber de información es una regla de conducta para que en su proceder los tratantes no se infieran daño, y en el caso de faltar a ese deber, al no proporcionar elementos de juicio de manera clara, sincera y transparente, la ley pretende que esa falta de lealtad no conduzca a perfeccionar un contrato que de haber sido conocidas esas circunstancias que no fueron reveladas, no se hubiera querido celebrar o se hubiera celebrado en condiciones distintas (Narváez, 2014, p. 195).

A esto se suma el llamado deber de colaboración mutua entre los tratantes, que equivale a auxiliarse recíprocamente, ello en función de una conducta y actitud que debe ser proactiva, positiva y marcada por el esfuerzo de que el intercambio de la información se exprese de manera eficiente. A esta cooperación se suma el deber de confidencialidad, es decir de reserva de la información que haya sido facilitada por los tratantes y, por tanto, a su no divulgación, salvo previa autorización (Ordóñez, 2005).

A nivel general, se identifica en la estructura del contrato de seguro dos partes; las condiciones o cláusulas generales y las cláusulas particulares (Isern, 2014). La primera corresponde a la columna vertebral del contrato, que lo permiten identificarlo respecto de los 
demás contratos de seguro, pero también los elementos fundantes del contrato (extensión del riesgo, tarifa aplicable, reglas de juego, términos y condiciones de las obligaciones y derechos que nacen del contrato); la segunda parte tiene que ver con estipulaciones convenidas entre las partes (Compiani, 2016).

A continuación se plantean los elementos o características básicas del contrato de seguro

- Consensual: el contrato de seguro es consensual, conforme a lo establecido en los artículos 824, 1036, 1046 y 1047 del C. de Co. En estos se precisa que dicho consenso queda limitado únicamente a dos elementos probatorios, el documento o la confesión. Asimismo, que "como un régimen contractual especial que se aparta, en aspectos puntuales, del régimen general aplicable a las obligaciones y a los contratos de derecho privado" (Mantilla y Clavijo, 2003, p. 225).

De acuerdo con Vigil (2016) la consensualidad en el contrato de seguro estaría probada básicamente con la póliza, que es la que le da vida jurídica al mismo, en el que deben estar consideradas las condiciones generales del contrato: razón social del asegurador, nombre del tomador, identificación del asegurado o beneficiario, calidad que tiene el tomador, identificación precisa de la cosa o persona sobre las que se contrata el seguro, vigencia del contrato, suma o modo asegurado, prima, riesgos, fecha y firma del asegurador y demás condiciones propias de cada seguro.

Frente a este consenso, existe una parte de la doctrina que plantea que el mismo es solemne, debido a estas restricciones probatorias que plantean en sí el desarrollo de elementos claramente solemnes (Becerra, 2014). 
- Bilateral: es bilateral el contrato de seguro porque intervienen dos partes contratantes que se obligan; la aseguradora y el tomador, las cuales asumen obligaciones al momento de suscribirlo. La primera de adquirir la obligación de asumir un riesgo y pagarlo en caso de ocurrir un siniestro, lo que se considera como una obligación condicional; en tanto que para este último, el tomador, la de pagar la prima y salvaguardar el estado del riesgo, siendo con ello, una obligación pura y simple (López, 2015).

- Oneroso: esto ocurre porque “el TOMADOR se grava con la obligación de pagar la prima, y la ASEGURADORA la de amparar el riesgo y de pagar la indemnización en caso de ocurrir el siniestro amparado" (Becerra, 2014, p. 22). Ello significa que cada parte se grave, mientras que la contraparte se beneficia. En estos casos el deudor debe responder hasta la culpa leve respecto a las obligaciones a su cargo, llevando así a hablar de un beneficio recíproco (Aguilar y Díaz, 2012).

- Aleatorio: ello debido a que en el contrato no aplica la teoría de la imprevisión, ya que todo depende de las condiciones de siniestralidad, es decir de una contingencia de ganancia o pérdida. Aun así, la doctrina no ha sido ajustada a ello, ya que planteado que "para la aseguradora el contrato de seguro no es propiamente aleatoria, porque ella está en condiciones de conocer de antemano y en una forma global las posibilidades ganancia o pérdida que puede genera su actividad" (Becerra, 2014, p. 23).

- Ejecución sucesiva: esta se manifiesta través del pago de la prima, bien a plazos o de un solo contado, frente al riesgo que se está amparando. Ahora la tipificación de ejecución sucesiva obedece también a que la labor de la aseguradora se encamina a la cobertura del riesgo en el tiempo de la vigencia del contrato. Es por ello que se plantea que la resolución no se procede por incumplimiento, sino por terminación (Penagos, 2005). 
- Adhesión: si bien se parte de que los contratos de adhesión no presentan la característica de ser contratos tipo, valga señalar que es la existencia de una voluntad contractual que impone unas condiciones, en tanto que la otra las acepta. Esto se encuentra especificado en la Ley 1328 de 2009 en los siguientes términos: "Contratos de adhesión son los contratos elaborados unilateralmente por la entidad vigilada y cuyas cláusulas y/o condiciones no pueden ser discutidas libre y previamente por los clientes, limitándose estos a expresar su aceptación o a rechazarlos en su integridad" (art. $2^{\circ}$, literal f). Ello confirma que las estipulaciones y cláusulas generales ofertadas por la aseguradora no son discutibles desde su comienzo (Romero y Velandia, 2008).

No sobra señalar cómo la adhesión no se predica de todo el contrato en sí, ya que, como se observó anteriormente, existen las posibilidades de que las partes hagan cambios al contrato de seguro, luego se puede hablar que la adhesión se encuentra condicionada a estos últimos acuerdos a los que se lleguen en el transcurso de la negociación (Torres, Uribe y Cortés, 2011).

Aun así, en palabras de Narváez (2014) los contratos de seguro, cuando de riesgos de determinada envergadura se traten, lo normal es que se lleve a cabo un proceso de negociación, en el que tratan aspectos específicos como son las “condiciones económicas de cobertura, los amparos contemplados, el deducible, el límite asegurado, los posibles sublímites, el restablecimiento o no de la suma asegurada" (p. 160). Pese a ello, se plantea por el mismo autor que el tema de la adhesión depende en cierta medida de la capacidad de reaseguro que exista en el mercado internacional, ya que este puede en ocasiones imponer determinadas cláusulas al contrato originario, como es v. gr., lo relacionado con la cooperación y control sobre los reclamos. 
- Indemnizatorio: se plantea que esta indemnización obedece ante todo a una reparación, pero no puede convertirse en un instrumento para el enriquecimiento del asegurado: “Los seguros de daños serán contratos de mera indemnización y jamás podrán constituir para él fuente de enriquecimiento. La indemnización podrá comprender a la vez el daño emergente y el lucro cesante, pero éste deberá ser objeto de un acuerdo expreso" (Código del Comercio, 1971, art. 1088).

Ello significa que la indemnización conlleva el pago del valor real del interés asegurado al momento del siniestro, a lo que se añade los perjuicios sufridos efectivamente por el beneficiario, que no necesariamente es el asegurado.

- Celebración y ejecución de buena fe: esta exigencia está determinada por que este tipo de contratos conlleva la carga de la buena fe exenta de culpa para las dos partes contratantes, luego ello implica que el asegurador conozca con claridad los riesgos, en tanto que el tomador el valor de la prima como los valores estipulados en caso de indemnización. En ese sentido, Becerra (2014) insiste en plantear que el de "seguros es un contrato de buena fe, pero, la buena fe calificada, que sobre pasa a la diligencia, decoro y honestidad normales de todo contrato, que se predica por igual de asegurador y tomador" (p. 27).

Esta buena fe calificada se expresa en tres aspectos: las condiciones del contrato no pueden ser lesivas, ambiguas u oscuras para el tomador; queda arropado bajo el principio de la buena fe y; en tercer lugar, que esta debe estar presente desde antes de la celebración del contrato.

Para Narváez (2014) la falta de buena fe conlleva a la penalización de este tipo de conductas, de ahí la importancia para que haya una puesta en práctica de una buena fe estricta 
que propenda por la defensa integral de las partes, bajo las condiciones de mutualidad, pero también que se salvaguarden los intereses de estas, a fin de salvar la institución del seguro.

- Intuitu Personae: Conforme a los artículos 648 y 651 del C. de Co., este tipo de contratos se hace atendiendo las calidades de las partes, tanto del asegurador, como persona jurídica, como del tomador o beneficiario, que es quien tiene interés en asegurarse.

De otro lado, en lo que tiene que ver con las etapas para el perfeccionamiento y creación de un contrato de seguro, se proponen tres fases básicas: proposición del seguro o conversaciones, diligenciamiento y expedición de la póliza y declaración del tomador o asegurador respecto de la valoración del riesgo (Becerra, 2014). El primer lapso corresponde a la propuesta, que bien puede surgir del tomador o del asegurador, generalmente en alguna forma impresa o virtual, y debe ajustarse a los elementos esenciales de un contrato.

La segunda etapa, diligenciamiento y expedición de la póliza, tiene su importancia en dos sentidos, práctico y jurídico, ya que corresponde, entre otros aspectos, a las estipulaciones expresas de las partes en todos y cada uno de los elementos esenciales a asegurar, la prima, el riesgo, las exclusiones y su duración y seguro en exceso (Restrepo, 2014). Precisando, jurídicamente, su valor está en que este documento es el principal y más idóneo medio de prueba con el que cuentan las partes.

En lo que respecta a la declaración exacta del asegurado respecto al riesgo, es un imperativo que este le informe al asegurador sobre la realidad del riesgo, así como el estado actual en que ese encuentra: “Al asegurador le queda muy difícil en la práctica constatar la exactitud de las declaraciones del tomador (...), pero si el tomador (...) defrauda (...) esa buena fe inicial, suministrando información falsa, tendenciosa, incompleta e inexacta, el asegurador puede dar por terminado el seguro" (Becerra, 2014, p. 31). 
De otro lado, en lo que respecta a la validez del contrato de seguro, se plantean inicialmente los siguientes supuestos jurídicos: objeto y una causa física y moral posible, el consentimiento libre y espontáneo y capacidad de las partes intervinientes.

En otro sentido, frente a la importancia del formulario de solicitud, Narváez (2014) recalca cómo la ley le impone al asegurado que declare la verdadera situación del riesgo, ya que ello implicaría sanciones muy específicas en caso de existir un incumplimiento: "En efecto, las respuestas del asegurado a las preguntas contenidas en el formulario de solicitud suministrado por el asegurador, deben ser veraces y completas a fin de facilitar a este el análisis de los riesgos que asumiría en caso de celebrar el contrato y determinar la prima correspondiente" (p. 172).

\section{El deber de informar.}

En lo que respecta a la información, es dable señalar que autores como Narváez (2014) deja en manos del asegurado la necesidad de informar, dejando al margen el tema del deber de informar claramente al asegurador:

Esos deberes de información, cooperación y lealtad que los tratantes se deben recíprocamente en las conversaciones y tratos que anteceden la formación del contrato son particularmente trascendentes en materia del contrato de seguro, porque el asegurador confía en las manifestaciones del tomador y no entre a verificarlas, porque en la práctica resultaría imposible hacerlo (...) por esa misma razón, el seguro es catalogado de manera unánime por la doctrina como de estrictísima buena fe. (Narváez, 2014, p. 177). 
Es pues claro para este autor que el deber información se encuentra como una de las conductas que debe llevarse a cabo bajo los criterios de fidelidad, lealtad y rectitud rigurosa. El soporte legal, según Narváez (2014) se encontraría en concreto en los artículos 1058 y 1158 del C. de Co., los cuales hablan de la figura jurídica de "reticencia e inexactitud en la declaración del estado del riesgo".

Al respecto Garzón (2015) precia que la reticencia es la omisión, “ausencia de manifestación de cosas que deben ser manifestadas o manifestación incompleta, distorsionada o confusa de las mismas" (p. 62). Asimismo, Gómez (2015) citando un fallo de la Corte Suprema de Justicia, subraya que la reticencia o inexactitud por parte del deudor conlleva necesariamente a la nulidad relativa, siendo con ello una razón para el no pago de la indemnización. Dado el interés que tiene para el presente estudio, se transcriben algunos apartes del artículo 1058 por considerarlos esenciales:

Artículo $1058 \mathrm{El}$ tomador está obligado a declarar sinceramente los hechos o circunstancias que determinan el estado del riesgo, según el cuestionario que le sea propuesto por el asegurador. La reticencia o la inexactitud sobre hechos o circunstancias que, conocidos por el asegurador, lo hubieren retraído de celebrar el contrato, o inducido a estipular condiciones más onerosas, producen la nulidad relativa del seguro.

Si la declaración no se hace con sujeción a un cuestionario determinado, la reticencia o la inexactitud producen igual efecto si el tomador ha encubierto por culpa, hechos o circunstancias que impliquen agravación objetiva del estado del riesgo (Código del Comercio, 1971, art. 1058). 
Conforme a este artículo, es claro que el legislador deja el tema de la responsabilidad de información en cabeza única y exclusivamente del tomador, en tratándose del riesgo, pero, se critica que no exista un articulado que le exija al asegurador que haga exactamente lo mismo para todas las eventualidades que tiene un contrato de seguro, sobre todo porque éste conoce a cabalidad e integridad el contrato de seguro, luego tiene certeza sobre cuáles son los puntos esenciales que debe conocer el tomador (Tascón, 2010).

Al no exigirse esta información, es evidente que el asegurador no va a querer insistir en que el tomador conozca todos los pormenores, ya que supone que al estar escritos son suficientes.

\subsubsection{Características del contrato de seguro de vida grupo deudores}

Los contratos de seguro de vida grupo deudores son seguros colectivos de personas, que si bien no tienen el carácter de compulsivo u obligatorio, se plantean, en principio, como un complemento idóneo para amparar bienes que se encuentran en calidad de hipotecados: "tiene como finalidad amparar contra el riesgo de muerte o de incapacidad total y permanente, por una suma equivalente al saldo insoluto del respectivo crédito, a las persona que son deudoras de un mismo acreedor" (Narváez, 2014, p. 700).

En este caso, el tomador corresponde a la entidad acreedora, que es la que tiene el carácter de beneficiario a título oneroso, en la medida que su interés por asegurar a sus deudores (codeudores incluidos también) en los casos en que resulte un saldo insoluto de la deuda como consecuencia del fallecimiento o incapacidad total o permanente de estos. Como bien se puede comprender, la vigencia del amparo está hasta que la obligación haya sido cancelada en su totalidad por el deudor (Ramírez, 2015). 
Es ante la vigencia del amparo que se han pronunciado varios doctrinantes, precisando que la misma corresponde al plazo acordado para la amortización del crédito. Asimismo, en el caso de encontrarse en mora el deudor, en el numeral $8^{\circ}$ de la Resolución 2735 de 1990 de la Superintendencia Bancaria precisa que el tomador, la entidad financiera, está obligada a mantener vigente el seguro de vida grupo deudores, aun cuando se encuentren en tal situación de mora, de ahí que se les exija a estas entidades el pago de las primas en las fechas previstas, teniendo en cuenta que dicho pago se debe mantener aun en los procesos judiciales, hasta que se haga efectiva:

El tomador estará obligado a mantener vigente el seguro de vida grupo deudores y a pagar las primas correspondientes, durante la totalidad del período en el cual subsista la deuda, aún en el caso en el cual el deudor se encuentre en mora, incluyendo la duración de los procesos judiciales que se inicien para hacer efectiva la misma (Superintendencia Bancaria, 1990, art $6^{\circ}$, numeral $8^{\circ}$ ).

Frente al tema de la incapacidad, total o permanente, los seguros tienen estipulado que los deudores no sobrepasen determinada edad, que regularmente son los 60 años, puesto que no existe un consenso por parte de las compañías aseguradoras. "El valor asegurado está representado por el saldo insoluto de la deuda y para esos efectos, se entiende que incluye el capital no pagado más los intereses corrientes, calculados hasta la fecha de fallecimiento del asegurado o de aceptación por parte de la compañía de seguros de la declaratoria de incapacidad total y permanente" (Narváez, 2014, p. 700).

De otro lado, el origen de esta clase de seguros se encuentra en la Resolución 217 de 1960 (Murcia y Rodríguez, 2002) en el que se creó como mecanismo que permitiera el amparo por riesgo de muerte de un deudor, en los criterios anteriormente mencionados, es 
decir por el valor del crédito o del saldo insoluto de la deuda. Su evolución normativa se aborda en el siguiente capítulo.

En cuanto a la caracterización, valga decir que este es un tipo de amparo o protección del crédito hipotecario aplicado por la entidad financiera cuando ocurra alguna eventualidad. Es por ello que el tomador de esta modalidad de contrato de seguro, es la entidad financiera que constituye un grupo de cartera hipotecaria con créditos vigentes, en el cual tiene como deudores a personas naturales y todas aquellas personas jurídicas que sean responsables del pago de dicho crédito o tengan el carácter de deudores.

De acuerdo con Narváez (2014) es evidente que este tipo de seguros no es por cuenta de un tercero, en la medida que la entidad financiera asume el carácter de tomador, luego sí tiene interés, ya que el no tomar este tipo de seguros le puede representar un perjuicio en los casos en el que el deudor fallezca o se encuentra con una incapacidad total o permanente.

En este mismo sentido, se plantea la necesidad de que el tomador, es decir la entidad financiera deba estar informando y actualizando periódicamente a la aseguradora respecto de los valores actualizados relativos al capital no pagado y los intereses corrientes. Ello con el objetivo de que cuando se produzca el fallecimiento o la incapacidad, la aseguradora esté en capacidad de dar pronta respuesta sobre el valor a cancelar. El hecho de que esta actualización no se lleve a cabo de forma periódica, puede generar consecuencias adversas para la entidad financiera, ya que tendría que asumir responsabilidades por las sumas aseguradas que no hayan sido actualizadas.

Otro de los aspectos característicos de este tipo de contrato de seguro es que el amparo tiene un carácter automático, en el entendido que su validez está desde el momento en que se 
desembolsa el crédito, siempre y cuando se cumplan los criterios establecidos por la aseguradora respecto a la edad de los deudores, como ya se mencionó anteriormente, así como el tema de la salud, en el cual se tenga evidencia de que goza de plena salud.

En los casos en que la edad del solicitante supere los 60 años o el valor asegurado en uno o varios créditos otorgados por la entidad financiera supere la suma acordada entre la aseguradora y la entidad financiera, o cuando el estado de salud del solicitante de acuerdo con lo expuesto en la declaración de asegurabilidad se ve en algún modo agravado, deja de surtir efecto la automaticidad del amparo (Narváez, 2014, p. 705).

Normalmente, este tipo de pólizas es contratado por un período de 3 años, momento en el cual se procede a la revisión de las condiciones y términos establecidos en cada anualidad, con el objetivo de determinar si los deudores cumplen con los criterios exigidos en cuanto a edad y estado de salud. No obstante, se debe aclarar que mientras el resultado técnico se emite, la vigencia de amparo se presenta desde el mismo momento del desembolso del crédito, aun cuando este procedimiento de entrega del crédito ya viene precedido de un estudio previo de la aseguradora para la inclusión de todos y cada uno de los deudores.

En cuanto a los amparos, valga decir que estos corresponden a muerte natural o accidental, homicidio, suicidio y los ya mencionados de la incapacidad, los cuales van desde el primer día de vigencia del contrato de seguro vida grupo deudores. Sobre los pagos de la indemnización, se tiene establecido que estos serán en un solo contado.

En relación con los beneficiarios, estos corresponden a la entidad financiera, Fogafin en segundo grado y los acreedores que tengan la calidad de beneficiarios a título oneroso, el cual cubre hasta el saldo insoluto de la deuda. 
De otro lado, en cuanto a la determinación de la prima, valga decir que esta se encuentra supeditada principalmente a la edad del asegurado, aun cuando también tiene que ver el estado de salud del mismo. Conforme a ello, el valor de la prima aumenta así como aumenta la edad de los deudores. Aun así, Narváez (2014) destaca que para grupos compuestos, de aproximadamente 200 asegurados, es posible que se apliquen tasas promedios:

Cuando se opta por este sistema se aplica una tasa igual para todos los integrantes del grupo, con el ánimo de facilitar el cálculo de las primas, la administración de la póliza y la determinación de los costos que el tomador trasladará a cada uno de los asegurados (Narváez, 2014, p. 717).

En lo que respecta al estado de salud, para la prima se identifican dos tipos de riesgos, los normales y los subnormales. Los primeros son aquellos deudores que no presentan circunstancias agravantes, mientras que los segundos, por presentar algunas deficiencias evidentes, requieren del pago de una prima más alta, como una especie de recargo.

De igual forma, en el manejo de la mora en el pago de la prima del seguro de vida grupo deudores, la Superintendencia Financiera ha sido clara en subrayar, como ya se mencionó en otro momento, que es conveniente mantener activa esta póliza, ya que en el evento de un siniestro, del fallecimiento o de la incapacidad permanente, la entidad financiera estará en capacidad de cobrar el saldo insoluto de la deuda más los intereses.

Se plantea por parte de Narváez (2014) que esbozar una hipótesis diferente, es decir de la exclusión de la póliza de aquellos deudores morosos, para ingresarlo posteriormente, 
una vez se haya puesto al día, es inequitativo debido a las circunstancias propias de un seguro de vida:

Porque existe continuidad en el amparo y esta afirmación se funda en la misma naturaleza del seguro de vida, vale decir, con el transcurso del tiempo el asegurado envejece y en esa misma medida va alcanzando niveles inferiores de probabilidad o esperanza de vida y el mismo envejecimiento del organismo (Narváez, 2014, p. 719).

Conforme a estos elementos integradores del seguro de vida grupo deudores, a continuación se desarrolla el marco normativo sobre el cual se funda este tipo de seguros.

\subsection{Marco normativo que rige el contrato de seguro de vida grupo deudores}

Las características ya establecidas de un contrato de seguro de vida grupo deudores lleva a plantear enseguida su definición normativa. En primer lugar, debe recordarse que es el Estado el que tiene la potestad para ejercer el debido control y vigilancia ininterrumpida del sector de los seguros, el cual va desde el mismo momento en que se crea la persona jurídica del asegurador, así como su estructuración y funcionamiento.

Ello porque es el Estado el que "supervisa sus resultados técnicos y financieros; evalúa sus pólizas y las notas técnicas que sirven de base a sus tarifas para que estas respondan a los principios de equidad y suficiencia” (Narváez, 2014, p. 99).

En ese sentido, en lo relativo a la constitución de una aseguradora, se plantea que estas entidades se deben sujetar al régimen que la Superintendencia Financiera de Colombia ha previsto para su vigilancia y control. Asimismo, las características y modalidades de las diversas ofertas que tienen estas compañías, que se materializan en un contrato de seguro, se enmarcan dentro del derecho privado, cuyo fundamento normativo se encuentra en el Decreto 
663 de 1993, así como en la Ley 795 de 2003, aun cuando es de aclarar cómo dicha actividad se contrae a la vigilancia del Estado, concretamente de la Superintendencia Financiera de Colombia, vigilante del sector financiero, bajo el entendido que se busca el amparo de derechos tanto del tomador como del asegurado y posibles beneficiarios.

En lo atinente al Estatuto Orgánico del Sistema Financiero, vale decir que su sustento se encuentra en la Constitución Política de 1991, así como en el Decreto 663 de 1993, que configura las directrices sobre cómo ha de llevarse a cabo la actividad aseguradora en el país. A través de este decreto se plantea la tutela de "los derechos de los tomadores, de los asegurados y crear condiciones apropiadas para el desarrollo del mercado asegurador, así como una competencia sana de las instituciones que participan en él” (art. 38).

Un aspecto de importancia que aborda dicho Estatuto Financiero, tiene que ver con el régimen de protección a tomadores de seguros y asegurados, el cual establece unas reglas y criterios para salvaguardar sus derechos. Una de estas reglas constituye la protección a la libertad de contratación, como en el caso de las entidades financieras que actúan como tomadoras para los seguros de vida grupo deudores, las cuales tienen que asumir procedimientos que puedan garantizar la libre concurrencia de oferentes, tal como queda expresado a continuación:

La Superintendencia Bancaria protegerá la libertad de tomadores y asegurados para decidir la contratación de los seguros y escoger sin limitaciones la aseguradora y, en su caso, el intermediario y aplicará las sanciones correspondientes cuando verifique conductas o prácticas que contraríen lo dispuesto en este Estatuto (Estatuto Orgánico del Sistema Financiero, 1993, art. 100). 
En este mismo sentido, el artículo en mención define como prácticas prohibidas el ofrecer reiteradamente políticas o tarifas con el desconocimiento los numerales 1 y 2 del artículo 184 del mismo Estatuto. Estos numerales son claros en señalar que los modelos de las pólizas y las tarifas ofrecidas, deben ser autorizados previamente por la Superintendencia Financiera. Asimismo. Se plantea también que dichas pólizas deben ajustarse a los siguientes criterios: contenido ceñido a las normas del contrato de seguro, utilizar una redacción de fácil comprensión para los asegurados y deben estar claramente destacados los amparos básicos y las exclusiones respectivas.

1. Modelos de pólizas y tarifas. La autorización previa de la Superintendencia Bancaria de los modelos de las pólizas y tarifas será necesaria cuando se trate de la autorización inicial a una entidad aseguradora o para la explotación de un nuevo ramo. En concordancia con lo dispuesto por el artículo 2o. de la Ley 389 de 1997, los modelos de las pólizas y sus anexos deberán enviarse a la Superintendencia Bancaria para su correspondiente depósito, en las condiciones que determine dicho organismo. No obstante lo anterior la autorización previa de la Superintendencia Bancaria será necesaria cuando se trate de la autorización inicial a una entidad aseguradora o de la correspondiente para la explotación de un nuevo ramo.

2. Requisitos de las pólizas. Las pólizas deberán ajustarse a las siguientes exigencias: a. Su contenido debe ceñirse a las normas que regulan el contrato de seguro, al presente estatuto y a las demás disposiciones imperativas que resulten aplicables, so pena de ineficacia de la estipulación respectiva;

b. Deben redactarse en tal forma que sean de fácil comprensión para el asegurado. Por tanto, los caracteres tipográficos deben ser fácilmente legibles, y 
c. Los amparos básicos y las exclusiones deben figurar, en caracteres destacados, en la primera página de la póliza (Estatuto Orgánico del Sistema Financiero, 1993, art. 184).

Otro de los asuntos tratados por el Estatuto Financiero, tiene que ver con la obligatoriedad de este tipo de seguros. En ese sentido el artículo 191 de dicho Estatuto expresa que sólo podrán ser obligatorios los seguros que han sido creados por ley; aspecto este que se aclara en el artículo 101 ibídem, en relación con bienes inmuebles de las entidades financieras, deja expresa la obligatoriedad de asegurarse contra los riesgos de incendio y terremoto, en su valor comercial y por la vigencia del crédito, pero frente al seguro de vida grupo deudores no consagra algún tipo de obligación.

Los inmuebles de propiedad de las entidades sometidas al control de la Superintendencia Bancaria y aquellos que les sean hipotecados para garantizar créditos que tengan o lleguen a tener a su favor, deberán asegurarse contra los riesgos de incendio o terremoto, en su parte destructible, por su valor comercial y durante la vigencia del crédito al que accede, en su caso (Estatuto Orgánico del Sistema Financiero, 1993, art. 101).

En postura de varios doctrinantes (Narváez, 2014) se dice que sería fundamental que la obligatoriedad en los seguros se incluyera igualmente este modelo de seguro de vida grupo deudores, ya que puede representar un beneficio para los deudores y sus beneficiarios, en tanto permite que los créditos de vivienda tengan un mejor soporte financiero, coadyuvando con ello en un mayor incremento de oferta de vivienda hipotecaria ante la cobertura de tales riesgos. 
Esta tarea de obligatoriedad del seguro de vida grupo deudores queda en cabeza de la Superintendencia Financiera, ya que las facultades que tiene en materia de inspección y vigilancia le posibilita para incluir este aspecto dentro del marco regulatorio de protección.

Ya en lo concerniente al seguro de vida grupo deudores, como se mencionó anteriormente, tiene su génesis en la Resolución 217 de 1960 de la Superintendencia Bancaria, pero después se hizo más específica mediante la Resolución 2356 de 1975, en el que definió el amparo por riesgo de muerte del deudor, bien por el valor del crédito o por el saldo insoluto, pero con un pacto de plazo inicial no inferior a 90 días. Asimismo, quedó expreso que el tomador sería el acreedor quien tendría el carácter de beneficiario a título oneroso (Narváez, 2013).

Ulteriormente, esta normativa es derogada por la Resolución 316 del 29 de enero de 1988, que toma en cuenta la nueva figura de valoración del crédito hipotecario como son las Unidades de Poder Adquisitivo Constante (UPAC). Bajo esta nueva Resolución, se fijan las tasas aplicables, tanto en pesos como en UPAC. No obstante, esta resolución es anulada por parte del Consejo de Estado en 1991.

Posteriormente, en Resolución 2735 de 24 de julio de 1990 la Superintendencia Bancaria genera una nueva regulación con los mismos objetivos de protección de los riesgos de muerte e incapacidad total y permanente de deudores que sean parte de un mismo acreedor. Al mismo tiempo se emite la Circular Externa 037 de julio de 1990, la cual no sólo derogó la Circular Externa 007 de 1988, sino que estructuró una nueva reglamentación para el seguro de vida grupo deudores: 
(i) Que el grupo de asegurados no fuera menor a 10 deudores; (ii) que el tomador pagara la prima; (iii) que el deudor interesado presentara una solicitud de ingreso al grupo asegurado; y (iv) que los nuevos contratos de seguro se adecuaran a las directrices contenidas en esta Circular y en la Resolución 2735 de 1990 (Corte Suprema de Justicia, 2011, expediente 76001)

No obstante, dicha Resolución fue anulada por el Consejo de Estado en Sentencia del 5 de marzo de 1999, en aspectos específicos como la anulación de la obligación que tenía el tomador, es decir la entidad crediticia acreedora, la que debía mantener el amparo mientras perdurara la deuda, inclusive en los casos de mora del deudor. Para el Consejo de Estado, imponer este tipo de obligaciones generaba una invasión de la Superintendencia en la órbita de la autonomía y libertad contractuales.

Finalmente, la Superintendencia Bancaria se vio urgida en proferir una nueva Circular Externa, la 052 de diciembre de 2002, en el que se insiste que este tipo de seguros cubren los riesgos de muerte e incapacidad total o permanente de los deudores frente a un mismo acreedor, quien es el que tiene la calidad de tomador y, por ende, debe hacerse responsable por los pagos de la prima: "En esta nueva preceptiva se ocupa de las solicitudes individuales de ingreso, de los certificados individuales que deben emitirse, de la determinación del saldo insoluto de la deuda y contempla la posibilidad de hacer extensivo el amparo codeudores (Narváez, 2014, p. 202).

En este marco regulatorio del seguro de vida grupo deudores es importante subrayar la importancia que tiene la Superintendencia Financiera de Colombia, ya que es la entidad que ejerce las competencias de policía administrativa, luego tiene la disponibilidad o facultad 
para regular la actividad administrativa a través de actos administrativo, tanto en el ámbito general como particular.

En ese sentido, esta entidad emitió concepto el 18 de noviembre de 2009, respecto a la responsabilidad de la aseguradora ante la posibilidad de amparar cualquier crédito que ha sido otorgado por una entidad financiera, que dada su importancia se transcribe en su integridad:

La posibilidad de tomar dicho seguro para amparar cualquier clase de crédito otorgado por una entidad financiera es facultativa y hace parte de la administración del riesgo crediticio implícito en esta clase de operación. La responsabilidad de la compañía aseguradora en este tipo de contrataciones, radica bajo condiciones normales, en la atención del pago de la indemnización al banco una vez ocurrido el siniestro -muerte del deudor-, el cual en principio será hasta el valor el saldo insoluto de la deuda a la época del fallecimiento del asegurado. Cuando las instituciones financieras actúen como tomadoras de seguros, cualquiera que sea su clase, por cuenta de sus deudores, deberán adoptar procedimientos de contratación que garanticen la libre concurrencia de oferentes de las pólizas (Superintendencia Financiera, 2009).

Este Concepto dado por la máxima autoridad en Colombia en materia de seguros, muestra cómo las entidades financieras están en capacidad de ampliar el portafolio de aplicación de este seguro, pues ello les permite tener un mejor manejo del riesgo, a la vez que se toman en cuenta otros criterios para definir si aprueba o no un crédito de cualquier línea que ofrezcan (hipotecario, libre inversión, etc.). 
Conforme a los criterios normativos ya señalados, tanto desde el ámbito legislativo, como el desarrollado por la Superintendencia Financiera de Colombia, a continuación se hace un análisis jurisprudencial sobre los aportes que desde las altas cortes vienen aplicando a este tipo de contratos de seguro.

\subsection{Análisis jurisprudencial sobre los contratos de seguro de vida grupo deudores}

Frente a los seguros de vida grupo deudores se ha presentado un aporte sustancial por parte de las altas cortes, recordando lo señalado por Díaz (2014) quien expresa que el desarrollo jurisprudencial frente al seguro de vida en Colombia, no siempre aporta las mejores soluciones, ello debido en algunos casos a la falta de integralidad del mismo seguro de vida o, en segundo lugar, por la intención de proteger derechos conculcados.

A partir de esta introducción, valga destacar que el siguiente análisis jurisprudencial se basará en aquellas demandas de protección de los usuarios contra las aseguradoras por negarse a hacer efectivo el pago del respectivo siniestro y cuyas pretensiones se orientaron a sustentar la vulneración de derechos fundamentales. La pertinencia de estas sentencias radica principalmente en poner en evidencia que las entidades aseguradoras no respetaron los derechos establecidos en los seguros de vida grupo deudores, luego permite identificar las perspectivas de efectividad de tales de derechos. Asimismo, en cuanto a la metodología utilizada, la misma se basó en el enfoque del precedente constitucional propuesto por López (2006) a partir del estudio de casos que, para la presente investigación, correspondió a las sentencias emitidas por la Corte Constitucional, siendo en concreto las siguientes: C-860 de 2006, T-086 de 2012, T-751 de 2012, T-222 de 2014, T-282 de 2016, T-240 de 2016 y T676 de 2016. 
Inicialmente, en la figura 1 se muestra la línea jurisprudencial, a partir del modelo de López, la cual se basa en el análisis de la ratio decidendi de los fallos constitucionales, la definición de la sentencia central a fin de identificar las sentencias hito (Ver Anexo A) y el respectivo estudio pormenorizado de cada una de las sentencias en sus aspectos sustanciales, partiendo su análisis en orden cronológico.

A partir de esta aclaración, es importante destacar la sentencia C-860 de 2006, puesto que identifica las funciones de inspección y vigilancia estatal a la Superintendencia Financiera, en tanto esta entidad se encarga de establecer las limitaciones y los términos de los contratos de seguro, por ser estas actividades claramente de interés público. Al respecto subraya esta Corte:

Dicha Superintendencia cuenta con la competencia legal para demandarle a las entidades vigiladas el cumplimiento de sus órdenes y requerimientos, potestad que se encamina, en últimas, a hacer cumplir la voluntad del legislador y a materializar la especial intervención en un sector económico sensible prevista por la Carta de 1991 (...) están acompañadas de una necesaria competencia sancionatoria, sin la cual el órgano gubernamental difícilmente lograría disciplinar a los operadores del mercado, y por ende, no alcanzaría los fines estatales para los cuales fue creada (Sentencia C860, 2006). 
Figura 1. Línea jurisprudencial del seguro de vida grupo deudores

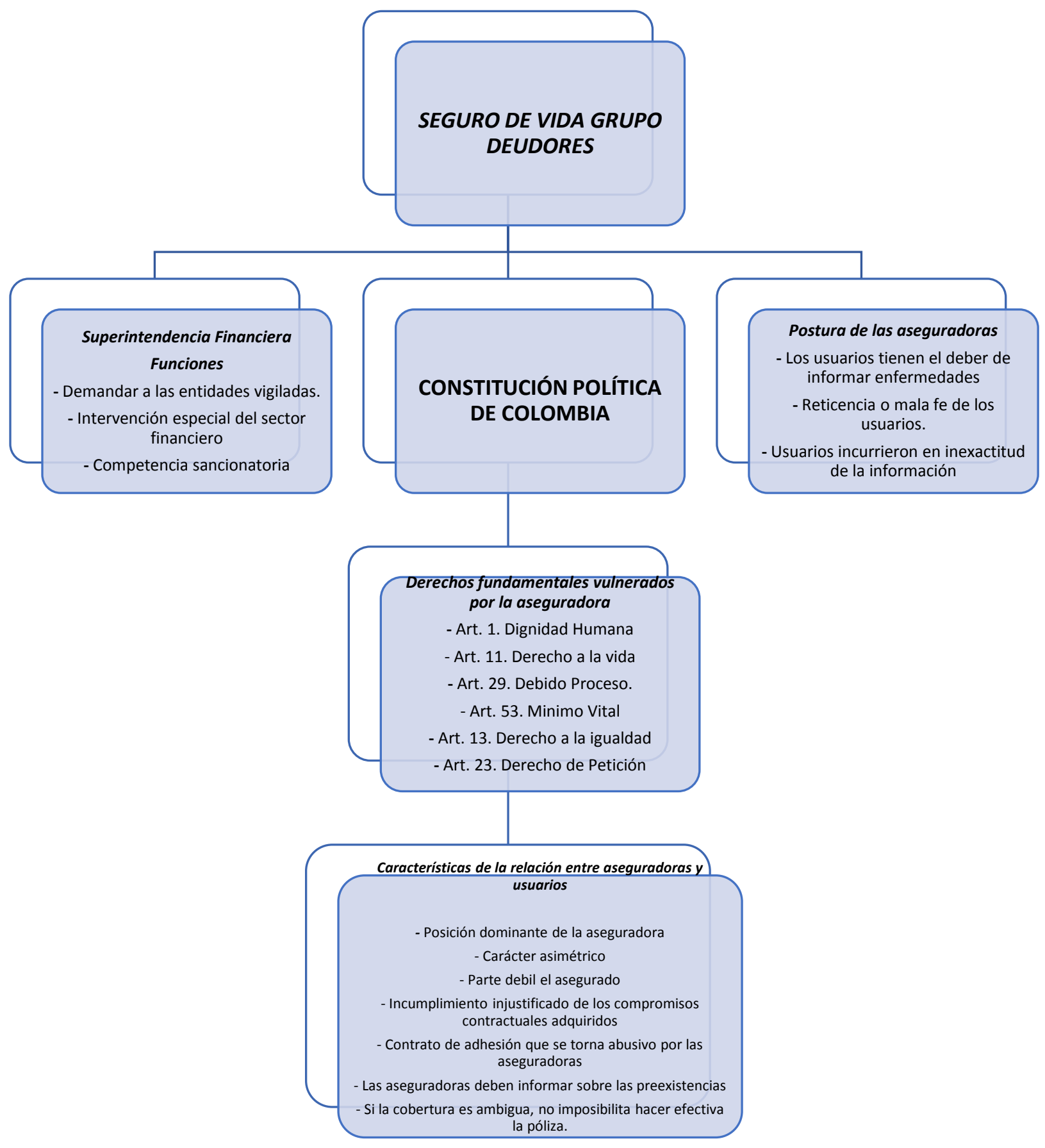

Fuente: elaboración propia. 
Asimismo, en sentencia T-832 de 2010, la Corte Constitucional se pronunció respecto a la vulneración de derechos fundamentales (debido proceso, igualdad y petición) que fueron ocasionados contra la deudora por parte del Banco Agrario y Colseguros S. A., como consecuencia de la pérdida de capacidad laboral que llegó al 77,5\% por una disfonía. Las entidades financieras se opusieron a aceptar el siniestro, aduciendo que esta enfermedad era anterior al momento de firmarse la póliza, luego no le cubría el derecho a la indemnización sobre el saldo insoluto de la obligación. Además, subrayan que la Acción de Tutela no procede por no versar sobre derechos fundamentales.

La Corte Constitucional decide amparar los derechos fundamentales que han sido vulnerados, para lo cual se fundamenta en varios elementos, entre los que se encuentra la posición dominante de las entidades que hacen parte del sistema financiero, frente a los usuarios, quienes no cuentan con los medios y el poder para amparar sus derechos. Esto es más evidente en el tema de los seguros, ya que si desean obtener un crédito financiero, se deben someter a las estipulaciones y requisitos contemplados en los contratos de seguro.

En ese sentido se subraya que las aseguradoras deben informar con claridad a los usuarios sobre las preexistencias o de la exclusión de alguna cobertura al inició de los contratos, sin lo cual el contrato quedará viciado de ambigüedades. Esto ocurrió en el caso presente, ya que la aseguradora no excluyó la cirugía prescrita por el médico tratante: "La carga de las preexistencias está en cabeza de la entidad aseguradora o de medicina prepagada y no del asegurado" (Corte Constitucional, Sentencia T-832, 2010).

La Corte Constitucional deja en claro que al no llevar a cabo la aseguradora un examen de salud, como tampoco el solicitarlo, para saber el estado de salud de la usuaria, no 
se estableció la constancia de exclusiones y preexistencias del contrato, siendo esto una clara responsabilidad de la aseguradora, luego su actuar fue negligente.

En una demanda similar, en la sentencia T-1018 de 2010, la Compañía Suramericana de Seguros señala que el deudor incurrió en reticencia e inexactitud respecto a los hechos o circunstancias que rodearon su enfermedad, luego se plantea la nulidad relativa del contrato de seguro al tomador y asegurado. Al respecto la Corte Constitucional precisa que el fin de este seguro de vida grupo deudores es sin duda prevenir o evitar un riesgo a través de medidas que son ineludibles como este tipo de contrato de seguro.

El seguro de vida grupo deudores que ofrecen las compañías de seguros, debe garantizar al asegurado que sus deudas por todas las líneas de crédito que haya utilizado están amparadas por la respectiva póliza, con lo cual se evita afectar el patrimonio familiar y el de sus codeudores, al sobrevenir fallecimiento o incapacidad permanente, resultando necesario señalar que los contratos de seguros llegan a tener incidencia frente a derechos fundamentales y han de precaver su afectación, en lo pertinente (Corte Constitucional, Sentencia T-1018, 2010).

Conforme a ello, es clara la necesidad de amparo por tratarse de un adulto mayor, con incapacidad, en condiciones de salud muy graves y en situación de desplazamiento forzado. Este cuadro de vida muestra inexorablemente un alto nivel de afectación de los derechos fundamentales, luego se requiere su amparo. Ahora, para el presente caso Bancolombia decidió condonar la deuda, luego se ampararon los derechos por carencia del objeto de la acción por ser un hecho superado. 
Nuevamente, mediante sentencia T-751 de 2012, la Corte Constitucional aborda la vulneración de derechos fundamentales ocasionados por la negativa de Seguros Alfa S. A., posteriormente bajo el nombre de BBVA Seguros de Vida Colombia S.A. y el Banco BBVA de amparar la póliza de vida grupo deudores. La demandante fue diagnosticada con deficiencia por esquizofrenia en el año 2010, declaran una pérdida de capacidad laboral del 91,5\%, pero la aseguradora lo negó aduciendo un cáncer de la deudora del año 2000, que según esta no fue incluida en las preexistencias, de ahí que se diga que hubo reticencia de la asegurada.

En la misma tutela T-751 de 2012 se resuelve otra demanda, pero esta vez contra Banco Davivienda - Seguros Bolívar; en los cuales estos argumentan reticencia del asegurado al no informar las enfermedades que tenía en el momento de hacer el contrato de seguro de vida grupo deudores.

El juez constitucional, frente a este tema, plantea que si bien el artículo 1058 del C. de Co., obliga a que se declare de forma abierta y sincera los hechos sobre los cuales se determina el estado del riesgo, situación que el asegurador, en virtud de tal artículo, deben conocer de forma razonable, pues ello determina el alcance de la contraprestación. Pero, añade enseguida la Corte Constitucional que al estar ambigua una cobertura, no se puede por ello negar la póliza al asegurado:

La carga de declarar sinceramente la información relevante para la determinación del estado de riesgo (en este caso, el estado de salud) no puede traducirse en una imposibilidad absoluta de hacer efectiva la póliza, como consecuencia de un establecimiento ambiguo de la cobertura, mediante cláusulas simplemente genéricas o mediante una alusión descontextualizada de las condiciones generales del contrato, 
carente de la precisión que se obtiene mediante las condiciones específicas del mismo (Corte Constitucional, Sentencia T-751 de 2012).

Reitera en la sentencia, que la jurisprudencia de la Corte Constitucional sólo se pronuncia en materia de contrato de seguros cuando considera que alguno de estos negocios jurídicos presenta incidencia en los derechos fundamentales y cuando se cumplen las condiciones para aplicar el principio de subsidiariedad.

En este caso, al igual que los anteriores, la Corte Constitucional decide amparar los derechos fundamentales que han sido vulnerados por la aseguradora, de ahí que ordene a las aseguradoras pagar los saldo insolutos de las obligaciones, revocando con ello los fallos de primera y segunda instancia, que habían sido contrarios a los demandantes.

Plantea enseguida la Corte, que pese a que el mecanismo de tutela no está diseñado para el análisis de asuntos en materia contractual, sobre todo por razones netamente económicas, el hecho de que se configure una afectación sustancial de derechos fundamentales, amerita la intervención de esta Corporación, como en el presente caso, en el que hay una amenaza de vulneración del derecho a una vivienda digna y al mínimo vital.

Cabe anotar que las accionantes podrían acudir a la jurisdicción ordinaria para exponer ante ella sus diferencias con las aseguradoras; sin embargo, esa vía judicial no se ofrece como una protección oportuna y efectiva para sus derechos fundamentales, teniendo en cuenta que está en riesgo cierto su derecho al mínimo vital, por lo que se requiere, de ser factible conforme a los términos del contrato de seguro, adoptar medidas urgentes para evitar un perjuicio irremediable. Bajo estos 
supuestos la acción de tutela se torna procedente incluso como mecanismo definitivo de protección constitucional (Corte Constitucional, sentencia T-751, 2012)

En consecuencia, la Corte subraya que este tipo de prácticas de las entidades financieras como de las aseguradoras es abusiva, sobre todo en los contratos de adhesión, en el que es fundamental que prime el principio de la buena fe de las partes en el contrato de seguro y se tenga en cuenta que los deudores se encuentran en algunos casos en situación de vulnerabilidad manifiesta.

Otro de los problemas jurídicos abordado por la Corte Constitucional correspondió al de la sentencia T-282 de 2016, en el que se presenta un conflicto de derechos y garantías constitucionales. Por un lado, la entidad financiera y la aseguradora, las cuales se abstienen de pagar la póliza y, en consecuencia, proceden con el proceso ejecutivo, argumentando que la deudora no informó de una enfermedad, cuando esta no se encuentra relacionada con la condición originaria del siniestro. De otro lado, está la accionante, deudora de la entidad financiera y con un contrato de seguro de vida grupo deudores, quien alega la violación al debido proceso y al mínimo vital.

Para la Corte Constitucional, soportada en otras sentencias de la misma Sala, subraya el carácter asimétrico de este tipo de contratos, ya que la parte débil siempre es el asegurado o el beneficiario, en tanto que la parte fuerte se encuentra en la aseguradora, que despliega todo su poder y conocimiento para fijar unilateralmente las condiciones de los contratos. Subraya enseguida la Corte, que estas entidades “en el curso de la relación negocial — se ha observado por parte del legislador histórico- - de manera no infrecuente, esquivan o dilatan injustificadamente el cumplimiento de sus compromisos" (Corte Constitucional, Sentencia T-282/2016). 
En este caso, el alegato de la aseguradora de que la deudora había incumplido sus obligaciones por reticencia, es decir de mala fe, no es recibido en buena forma por la Corte Constitucional, en la medida que no se encuentra una relación de causalidad entre la preexistencia alegada (reticencia) y la ocurrencia del siniestro:

En consecuencia, la decisión deliberada, arbitraria y abusiva de negar el pago del seguro (...) devino en la vulneración del derecho al debido proceso de la accionante por parte de BBVA Seguros de Vida S.A. Sin embargo, aunado a esto, esta actuación irregular por parte de la aseguradora configuró una vulneración de los derechos fundamentales al mínimo vital y vida digna de la accionante (Corte Constitucional, Sentencia T-282, 2016).

Conforme a esta decisión, la Corte Constitucional resuelve obligar a la aseguradora a pagar los saldos insolutos de las obligaciones crediticias de la accionante a la entidad financiera, así como la suspensión del proceso ejecutivo llevado a cabo en estrados judiciales y el levantamiento del embargo ante la Oficina de Registro.

De igual recibo ha tenido para la Corte Constitucional otros casos similares, en el que se ampara la vulneración de derechos fundamentales de los deudores, ante las acciones desplegadas por parte de las entidades financieras y las respectivas aseguradoras en el marco de los contratos de seguro de vida grupo deudores, ya que también se están contraviniendo los postulados emitidos por la Superintendencia Financiera.

Estos razonamientos se encaminan a que la entidad financiera continúe pagando la prima, en calidad de tomador, hasta tanto no se resuelvan los casos de enfermedad 
permanente de los deudores. De no hacerlo, no sólo se vulneran derechos fundamentales, sino que se va en contravía de fundamentos legales claramente establecidos por esta entidad.

En síntesis, tal como se puede apreciar, el problema jurídico asumido por la Corte Constitucional no se centró tanto en el deber de información que tienen las aseguradoras frente a los consumidores, sino a contrario sensu, en que la información aportada por los usuarios a las aseguradoras, si esta era parcial o insuficiente, no se puede asumir como una causal para negar el pago del siniestro. El soporte para tal decisión se funda en que si la información presenta problemas, ello obedece más a una ineficaz gestión por parte de la aseguradora. Aunado a ello, tal como se muestra en la figura 1, los derechos fundamentales vulnerados por estas entidades muestran el alto nivel de asimetría y posición dominante de estas organizaciones, las cuales niegan derechos establecidos en los propios contratos.

\subsection{Estudio de la aplicación del contrato de seguro de vida grupo deudores en tres compañías aseguradoras}

Para tener una visión integral sobre el objeto de estudio, se hizo una indagación a diversas aseguradoras sobre los elementos constitutivos del seguro de vida grupo deudores encontrando los siguientes resultados de las empresas Aseguradora Solidaria de Colombia, Seguros BBVA y Seguros Mapfre.

Tabla 1. Elementos constitutivos del seguro de vida grupo en Colombia de las compañías de seguro

\begin{tabular}{|l|l|l|l|}
\hline & Aseguradora solidaria & Seguros BBVA & MAPFRE \\
\hline Reconoce & $\begin{array}{l}\text { Saldo insoluto de la } \\
\text { deuda al tomador. }\end{array}$ & $\begin{array}{l}\text { Saldo insoluto de la } \\
\text { deuda al tomador. }\end{array}$ & $\begin{array}{l}\text { Saldo insoluto de } \\
\text { la deuda al } \\
\text { tomador. }\end{array}$ \\
\hline Cobertura en años & Sin límite de edad, & $\begin{array}{l}\text { Clientes hasta 74 años y } \\
\text { 364 días de edad; para }\end{array}$ & \\
\hline
\end{tabular}




\begin{tabular}{|c|c|c|c|}
\hline & & $\begin{array}{l}\text { pensionados hasta los } \\
79 \text { años y } 364 \text { días de } \\
\text { edad }\end{array}$ & \\
\hline Amparo Básico & $\begin{array}{l}\text { Riesgo de muerte. } \\
\text { Exclusiones: Las } \\
\text { preexistencias que no } \\
\text { hayan sido autorizadas } \\
\text { por la aseguradora }\end{array}$ & $\begin{array}{l}\text { homicidio, suicidio, } \\
\text { muerte por cualquier } \\
\text { causa }\end{array}$ & $\begin{array}{l}\text { homicidio, } \\
\text { suicidio, muerte } \\
\text { por cualquier } \\
\text { causa }\end{array}$ \\
\hline Amparos adicionales & $\begin{array}{l}\text { Incapacidad total y } \\
\text { permanente. El evento } \\
\text { generador haya sido } \\
\text { posterior a la fecha del } \\
\text { contrato. } \\
\text { Enfermedad grave } \\
\text { (cáncer, infarto del } \\
\text { miocardio, accidente } \\
\text { cerebro vascular, } \\
\text { afección arteria } \\
\text { coronaria, trasplante } \\
\text { de órganos vitales) } \\
\text { Gastos funerarios } \\
\text { Auxilio funerario } \\
\text { Exclusiones: evento } \\
\text { generador anterior a la } \\
\text { fecha de la firma del } \\
\text { contrato o que haya } \\
\text { sido provocado por el } \\
\text { asegurado. Trasplantes } \\
\text { de determinados } \\
\text { órganos. } \\
\text { Quedan excluidas las } \\
\text { enfermedades graves } \\
\text { cuando son } \\
\text { consecuencia de otras } \\
\text { enfermedades como el } \\
\text { SIDA, presencia del } \\
\text { virus VIH, cáncer de } \\
\text { seno o matriz, tumores } \\
\text { de la piel, cáncer in situ } \\
\text { no invasivo, } \\
\text { enfermedades o } \\
\text { malformaciones } \\
\text { congénitas, } \\
\text { enfermedades } \\
\text { preexistentes, estado } \\
\text { de coma provocado por } \\
\text { el alcohol. }\end{array}$ & $\begin{array}{l}\text { la sufrida por el } \\
\text { asegurado como } \\
\text { resultado } \\
\text { de una lesión o } \\
\text { enfermedad, que le } \\
\text { impida total y } \\
\text { permanentemente } \\
\text { realizar cualquier } \\
\text { actividad u ocupación. } \\
\text { Dicha incapacidad se } \\
\text { considerará siempre y } \\
\text { cuando haya persistido } \\
\text { por un periodo continuo } \\
\text { no } \\
\text { inferior a ciento veinte } \\
\text { (120) días comunes y } \\
\text { cuando la } \\
\text { pérdida de la capacidad } \\
\text { laboral calificada en } \\
\text { primera } \\
\text { instancia por el médico } \\
\text { determinado por la } \\
\text { aseguradora } \\
\text { y en las demás } \\
\text { instancias por las juntas } \\
\text { regional y } \\
\text { nacional de calificación } \\
\text { de invalidez, sea } \\
\text { superior al } \\
50 \% \text { y no haya sido } \\
\text { provocada a sí mismo } \\
\text { por el } \\
\text { asegurado. }\end{array}$ & $\begin{array}{l}\text { Incapacidad total } \\
\text { y permanente. El } \\
\text { evento generador } \\
\text { haya sido } \\
\text { posterior a la } \\
\text { fecha del } \\
\text { contrato. } \\
\text { Enfermedad grave } \\
\text { (cáncer, infarto } \\
\text { del miocardio, } \\
\text { accidente cerebro } \\
\text { vascular, afección } \\
\text { arteria coronaria, } \\
\text { trasplante de } \\
\text { órganos vitales) } \\
\text { Gastos funerarios } \\
\text { Auxilio funerario } \\
\text { Exclusiones: } \\
\text { evento generador } \\
\text { anterior a la fecha } \\
\text { de la firma del } \\
\text { contrato o que } \\
\text { haya sido } \\
\text { provocado por el } \\
\text { asegurado. } \\
\text { Trasplantes de } \\
\text { determinados } \\
\text { órganos. } \\
\text { Quedan excluidas } \\
\text { las enfermedades } \\
\text { graves cuando } \\
\text { son consecuencia } \\
\text { de otras } \\
\text { enfermedades } \\
\text { como el SIDA, } \\
\text { presencia del } \\
\text { virus VIH, cáncer } \\
\text { de seno o matriz, } \\
\text { tumores de la } \\
\text { piel, cáncer in situ }\end{array}$ \\
\hline
\end{tabular}




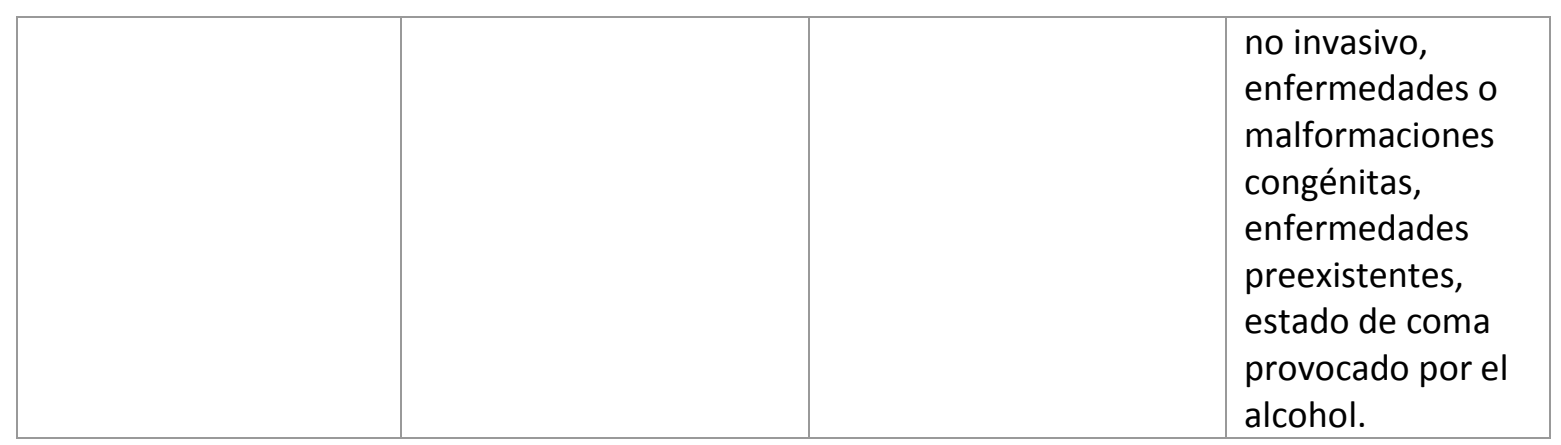

Fuente: elaboración propia.

Conforme a la tabla 1, este es un producto que se orienta a todas aquellas empresas que otorguen créditos de forma masiva, en el que su objetivo es "Proteger al grupo asegurado que sea deudor de un mismo acreedor, garantizando el pago de las obligaciones adquiridas por los asegurados para con el acreedor (Tomador) por los eventos cubiertos por la póliza" (Aseguradora Solidaria, 2017).

En el caso de las aseguradoras la cobertura es sin límite de edad y cubre cualquier causa de muerte (homicidio, suicidio). Además, exigen un examen médico para poder ingresar a la póliza de vida grupo deudores, de ahí que se tenga una red de convenios para que los posibles deudores hagan su respectivo examen.

En la web de la Aseguradora Solidaria (2017) aparece una "Declaración del estado del riesgo y sanciones por inexactitud o reticencia” basada en el artículo 1058 del C. de Co., con los siguientes términos: "El tomador del seguro está obligado a declarar sinceramente los hechos o circunstancias que determinan el estado del riesgo, según el cuestionario que le sea propuesto por el asegurador. La reticencia o la inexactitud produce la nulidad relativa del seguro". Además de este criterio, presente en todas las aseguradoras analizadas, en la anterior tabla se mostró el comparativo de las tres entidades aseguradoras.

\subsection{Conclusiones}


Primera. Las características determinadas en los contratos de seguro de vida grupo deudores, permiten identificarlo como un contrato de adhesión, en el que están presentes dos entidades financieras en posición dominante (bancos y aseguradoras) frente a un tercero que es el asegurado, cuya función se limita a aceptar los criterios, alcance, cobertura y valor de este tipo de contratos.

Segunda. Frente a esta condición de los contratos de vida grupo deudores, el análisis de la línea jurisprudencial para los casos analizados y sin que ello signifique que sea la regla general, permitió identificar que las aseguradoras y los bancos vulneraron derechos fundamentales de los deudores tales como el debido proceso, mínimo vital, igualdad, derecho de petición, derecho a la familia, alimentación y salud principalmente.

Tercera. El análisis jurisprudencial también puso en evidencia que en el contrato de seguro de vida grupo deudores se podría estar presentando conflicto de interés entre el tomador y la aseguradora, ello con el fin de afectar derechos de terceros, como es el caso del deudor. Esto obedece a que en los fallos analizados por la Corte Constitucional, se logró patentizar que tomador y aseguradora pertenecían a un mismo grupo, v. gr. entre el Banco BBVA y Seguros BBVA, así como Banco Davivienda y Seguros Bolívar. Esto conlleva a suspicacias cuando se pudo demostrar que las acciones llevadas a cabo por las entidades financieras involucradas, vulneraban derechos fundamentales de los deudores.

Cuarta. Si bien es cierto que la Corte Constitucional no se ha pronunciado al respecto del conflicto de interés, es claro que estas entidades financieras guardan similares intereses económicos, lo que impide que el deudor pueda contar con el apoyo o solidaridad del tomador del seguro, principal característica que puede surgir en un contrato como estos, pero lo que resulta es una solidaridad de este con la aseguradora, generándose con ello un conflicto de 
interés que no ha sido resuelto en debida forma, ni por la máxima autoridad como es la Superintendencia Financiera, como tampoco por los operadores judiciales.

Quinta. Igualmente, A modo de noción jurídica, se dice que el contrato de seguro incumbe la responsabilidad de una de las partes, el asegurador, que se exige a asumir un riesgo anticipadamente acordado, a cambio de un precio o prima pactado con el asegurado, que en caso de plasmar en un siniestro, tiene el deber de subsanar la suma que previamente se hubiere convenido.

Sexta. La incertidumbre, respecto al riesgo, se plantea en dos sentidos, la objetiva y subjetiva. La primera tiene que ver la contingencia de que se realice un acontecimiento futuro, pero que se excluya la época en que tal se pueda presentar. No es lo mismo con la incertidumbre subjetiva, que sería entendida como un acontecimiento que ya se ha presentado, pero que los contratantes ignoran que ya haya ocurrido, es decir que el hecho ya existe, pero que los extremos del contrato lo olvidan en su totalidad.

Séptima. Frente al tratamiento dado por las aseguradoras al seguro de vida grupo deudores, se observó que su centro de interés está en las empresas que otorgan créditos de forma masiva, destacándose que la cobertura no tiene límite de edad y cubre cualquier causa de muerte, bien sea homicidio o suicidio. Asimismo, dada la experiencia que tienen en el ramo, en la actualidad se exige un examen médico para poder ser aceptado como parte de la póliza de vida grupo deudores, para lo cual les presenta a los deudores una oferta de convenios con entidades de salud para el respectivo examen.

\subsection{Referencias}


Agobian, H. J. (2008). La prima en el contrata de seguros en la legislación venezolana. Caracas: Universidad Católica Andrés Bello. Maestría Derecho Mercantil. Recuperado de http://biblioteca2.ucab.edu.ve/anexos/biblioteca/marc/texto/AAR8253.pdf

Aguilar, R. J. y Díaz, B. (2012). Análisis y evaluaicón de la operatividad del mercado de seguros en Ecuador y propuesta de un modelo que facilite la asesoría a personas naturales y jurídicas. Ecuador: Universidad Politécnica Salesiana. Recuperado de http://dspace.ups.edu.ec/bitstream/123456789/2186/13/UPS-GT000276.PDF

Aranda, O. y Castillo, N. A. (2010). Valor de rescate y reserva matemática del seguro de vida individual en México. Recuperado de http://intermat.fciencias.unam.mx/ValRescRM.pdf

Arias, G. V. (2015). De la legitimación en la causa de tercero en la reclamación de la indemnización derivada del seguro de vida grupo deudores. Cali: Pontificia Universidad Javeriana. Facultad de Humanidades, Carrera de Derecho.

Aseguradora Solidaria de Colombia. (2017). Vida Grupo Deudores. Recuperado de https://www.aseguradorasolidaria.com.co/seguro_vida_grupo_deudores

Aseguradora Solidaria de Colombia. (2017). Póliza de Seguro de vida en grupo. Condiciones $\begin{array}{lll}\text { generales. } & \text { Recuperado de }\end{array}$ https://www.aseguradorasolidaria.com.co/userfiles/file/Condiciones\%20generales\% 20p\%C3\%B3liza\%20de\%20seguro\%20de\%20vida\%20en\%20grupo.pdf

Badillo, J. A. (2010). El dolo y la culpa grave en el contrato de seguro. Revista Estudios Jurídicos UNESP. 14(20), 87-112. 
Banco BBVA. (2017). Póliza de Seguro de vida grupo. Recuperado de https://www.bbvaseguros.com.co/fbin/mult/Condiciones_Generales_Vida_Grupo_D eudores_y_anexos_de_ITP_deudores_Definitivo_tcm1166-557208.pdf

Becerra, M. H. (2011). Manual básico lo que un usuario de seguros debe saber. Bogotá: Pontificia Universidad Javeriana. Especialización en derecho comercial. Recuperado de https://repository.javeriana.edu.co:8443/bitstream/handle/10554/9980/BecerraGome zMarthaElena2011.pdf?sequence $=1 \&$ isAllowed $=\mathrm{y}$

Becerra, R. (2014). Nociones fundamentales de la teoría general y regímenes particulares del contrato de seguro. Bogotá: Pontificia Universidad Javeriana.

Cantos, W. O. (2011). Implementación de seguro en tarjetas de crédito.

Cardona, N. (2013). Consideraciones sobre el seguro de cumplimiento. Bogotá: Pontificia Universidad Javeriana. Facultad de Derecho. Recuperado de https://repository.javeriana.edu.co/bitstream/handle/10554/14914/CardonaRiosNatal y2013.pdf? sequence $=1$

Casallas, A., Martínez, A. P. y Parra, N. O. (2006). Administración de riesgos en las compañías de seguros. Bogotá: Universidad de la Sabana. Instituto de Postgrados. Especialización en Seguros y Seguridad Social. Recuperado de https://intellectum.unisabana.edu.co/bitstream/handle/10818/5247/129881.pdf?sequ $\underline{\text { ence }=1}$

Colombia. Corte Constitucional. (2006). Sentencia C-860 (18, octubre, 2006). M. P. Dr. Humberto Antonio Sierra Porto. 
Colombia. Corte Constitucional. (2010). Sentencia T-832 (21, octubre, 2010) M. P. Dr. Nilson Pinilla P.

Colombia. Corte Constitucional. (2010). Sentencia T-1018 (9, diciembre, 2010). M. P. Nilson Pinilla P.

Colombia. Corte Constitucional. (2012). Sentencia T-751 (26, septiembre, 2012). M. P. María Victoria Calle Correa.

Colombia. Corte Constitucional. (2016). Sentencia T-282 (1, junio, 2016). M. P. Gloria Stella Ortiz Delgado.

Compiani, M. F. (2016). El régimen jurídico del contrato de seguro en el derecho argentino. Actualidad y perspectivas. Revista Actualidad Jurídica. (5), 8-35.

Congreso de Colombia. (2003). Ley 795 (14, enero, 2003). Por la cual se ajustan algunas normas del Estatuto Orgánico del Sistema Financiero y se dictan otras disposiciones.

Congreso de Colombia. (2009). Ley 1328 (15, julio de 2009). Por la cual se dictan normas en materia financiera, de seguros, del mercado de valores y otras disposiciones.

Corte Suprema de Justicia. Sala de Casación Civil. (2011). Sentencia 76001 (30, junio, 2011). M. P. Edgardo Villamil Portilla.

Delgado, J. M. (2008). La reanudación del contrato de seguro. México: Universidad Autónoma de Nuevo León. Recuperado de http://eprints.uanl.mx/1391/1/1020150315.PDF

Díaz, A. (2008). El siniestro en los seguros de responsabilidad civil con cláusula claims made. Recuperado de 
http://www.amis.com.mx/InformaWeb/Documentos/Archivos/02-

ImplicacionesJuridicas,Dr.ArturoDiazBravo_AMIS-15May08.pdf

Díaz, J. J. (2014). Tendencias jurisprudenciales del seguro de vida en Colombia. Análisis crítico. Revista RIS. 41(32), 175-196.

Gadea, E. (1986). La imposibilidad de la prestación y teoría del riesgo. Revista Themis. Revista de Derecho. (5), 69-72.

Garzón, I. A. (2015). Del contrato de seguro de vida: un estudio sobre las objeciones de pago de la indemnización por reticencia e inexactitud en la información. Bogotá: Universidad Católica de Colombia. Facultad de Derecho.

Gómez, C. A. comp. (2015). Jurisprudencia sobre el contrato de seguro. Corte Suprema de $\begin{array}{lll}\text { Justicia. } & \text { (1995-2014). } & \text { Recuperado de }\end{array}$ http://www.trtabogados.com/Documentos/JURISPRUDENCIAENSEGUROS19952014)T\&RABOGADOS(ED.2).pdf?d0bbda

Gómez, J. D. (2012). Nuevo estatuto del consumidor y el contrato de seguro. Bogotá: Universidad de la Sabana. Forum. Especialización en seguros y seguridad social. Recuperado de de https://intellectum.unisabana.edu.co/bitstream/handle/10818/6658/JUAN\%20DIEG O\%20G\%C3\%93MEZ\%20P.\%20\%28T\%29_159326.pdf?sequence=1\&isAllowed= y

Guzmán L. E. (2012). El contrato de seguro de vida de cara a la eventual decisión del asegurado o su familia de no prorrogar su vida con medios artificiales. Bogotá: Universidad de La Sabana. Instituto de Posgrados Forum. Recuperado de 
https://intellectum.unisabana.edu.co/bitstream/handle/10818/2990/luz_esperanza_gu zman_bautista.pdf?sequence $=1$

Isern, M R. (2014). Las condiciones generales del contrato de seguro y la protección del asegurado en el derecho español. Revista boliv. de Derecho. (18),98-121.

López, D. E. (2006). El derecho de los jueces. $2^{\circ}$ Ed. Bogotá: Editorial Legis.

López, J. M. (2015). La acción directa del damnificado contra la aseguradora y el llamamiento en garantía en materia de seguros de responsabilidad civil por daños contra terceros. Ecuador: Universidad Andina Simón Bolívar. Recuperado de http://repositorio.uasb.edu.ec/bitstream/10644/5021/1/T1982-MDE-Lopez-

La\%20accion.pdf

Mantilla, F. y Clavijo, L. E. (2003). El error del asegurador en el contrato de seguro. Revista Estudios Socio-jurídicos. 5(2), 224-241.

Marcano, J. (2014). Naturaleza jurídica del contrato de seguros por daños a terceros. Venezuela: Universidad José Antonio Páez. Recuperado de https://bibliovirtualujap.files.wordpress.com/2011/04/marcano-josmary.pdf

Medina, S. L. y Reina, W. (2004). Reticencia e inexactitud en el contrato de seguro. Bogotá: Pontificia Universidad Javeriana. Facultad de Ciencias Jurídicas. Recuperado de http://www.javeriana.edu.co/biblos/tesis/derecho/dere6/DEFINITIVA/TESIS70.pdf

Mejía, H. (2017). Gestión integral de riesgos y seguros: para empresas de servicio, comercio e industria (2a. ed.). Bogotá: Ecoe Ediciones 
Menchú, S. J. (2012). Incidencia de la nueva ley de seguro en el sector del seguro guatemalteco. Guatemala: Universidad Rafael Landivar. Facultad de Ciencias $\begin{array}{llll}\text { Jurídicas } & \text { y } & \text { Sociales. } & \text { Recuperado }\end{array}$ http://biblio3.url.edu.gt/Tesis/2012/07/01/Menchu-Sandra.pdf

Miranda, Suli. (2016). La ubérrima buena fe de las aseguradoras en el contrato de seguro en Colombia. Manizales: Universidad de Manizales. Recuperado de http://ridum.umanizales.edu.co:8080/xmlui/handle/6789/2981

Mosquera, F. X. (2010). El contrato de seguro de vida en el régimen jurídico Nicaragüense. Managua: Universidad Centroamericana, Facultad de Ciencias Jurídicas. Recuperado de http://repositorio.uca.edu.ni/272/1/UCANI3033.PDF

Murcia, D. M. y Rodríguez, G. K. (2002). Seguro de vida deudores. Comentario a la sentencia T-1165 de 2001 Corte Constitucional. Bogotá: Pontificia Universidad Javeriana. Facultad de Ciencias Jurídicas.

Narváez, J. E. (2013). Legitimación de la viuda y de los herederos bajo el seguro de vida grupo deudores. Revista RIS. 39(22), 69-111.

Narváez, J. E. (2014). El contrato de seguro en el sector financiero. $3^{\text {a }}$ ed. Bogotá: Grupo Editorial Ibáñez.

Ordóñez, A. E. (2005). Los deberes recíprocos de información en el contrato de seguro. Y Especialmente el deber de información del asegurador frente al tomador del seguro. Revista de Derecho Privado. (9), 75-115. 
Ordóñez, A. E. (2014). Las nuevas tendencias del derecho de seguros en las legislaciones más recientes de los países latinoamericanos. Revista de Derecho Privado. (26), 305349.

Peláez, M. (2004). De los sujetos jurídicos frente al contrato de seguro en el derecho colombiano. Asegurador, tomador, asegurado y beneficiario. Bogotá: Universidad EAFIT.

Penagos, A. (2005). El seguro de cumplimiento en la contratación administrativa. Bogotá: Pontificia Universidad Javeriana. Facultad de Ciencias Jurídicas. Recuperado de

Peña, F., Álvarez, N. y Busto, J. (2011). Derechos y obligaciones del empresario en el $\begin{array}{llll}\text { contrato } & \text { de } & \text { Seguro. } & \text { Recuperado }\end{array}$ http://www.javeriana.edu.co/biblos/tesis/derecho/dere7/DEFINITIVA/TESIS\%2056 . .pdf

Plaza, A., Cadena, P. J., Gutierrez, L.E. y Acero, C. E. (2006). Seguro de vida grupo familiar destinado a funcionarios de la fiscalía general de la nación. Contributivo voluntario. Bogotá: Universidad de la Sabana. Instituto de Posgrados. Recuperado de https://intellectum.unisabana.edu.co/bitstream/handle/10818/5249/129879.pdf?sequ $\underline{\text { ence }=1}$

Presidencia de Colombia. (1971). Decreto 410 (27, marzo, 1971) Por el cual se expide el Código del Comercio.

Presidencia de Colombia. (1993). Decreto 663 (2, abril, 1993) Por medio del cual se actualiza el Estatuto Orgánico del Sistema Financiero y se modifica su titulación y numeración. 
Ramírez, J. F. (2015). Legitimación del cónyuge sobreviviente y de los herederos con ocasión de los contratos de seguros de vida grupo deudores. Revista RIS. 43(24), 103-121.

Restrepo, V. (2014). Seguros de vida deudores. Pronunciamientos de la Corte Constitucional sobre la prescripción y el pacto de exclusiones en esta clase de seguros. Bogotá: Pontificia Universidad Javeriana. Facultad de Ciencias Jurídicas.

Romero, J. E. y Velandia, D. F. (2008). Cláusulas abusivas en el contrato de seguro. Bogotá: Pontificia Universidad Javeriana. Facultad de Ciencias Jurídicas. Recuperado de http://www.javeriana.edu.co/biblos/tesis/derecho/dere5/TESIS40.pdf

Seguros Mapfre. (2017). Condicionado póliza de seguro vida colectivo. Recuperado de https://www.mapfre.com.co/seguros-co/images/condicionado-vidacolectivos_tcm1124-221209.pdf

Seguros Mapfre. (2017). Vida Grupo Deudores. Recuperado de https://www.mapfre.com.co/seguros-co/empresas/vida-colectivos/grupodeudores/condiciones.jsp

Superintendencia Bancaria. (1990). Resolución 2735 (24, julio, 1990).

Superintendencia Financiera de Colombia. (2002). Circular Externa 052 de 2009.

Superintendencia Financiera de Colombia. (2009). Concepto 2009081947-001 (18, noviembre, 2009). Póliza de un seguro de vida a los deudores de créditos hipotecarios. $\quad$ Recuperado de https://www.superfinanciera.gov.co/SFCant/Normativa/PrincipalesPublicaciones/bo letinej/boletin2309/relacion.html 
Superintendencia Financiera de Colombia. (2014). Circular Externa 029 de 2014.

Tascón, J. B. (2010). La responsabilidad civil de los intermediarios de seguros. Medellín: Universidad Pontificia Bolivariana. Recuperado de https://repository.upb.edu.co/bitstream/handle/20.500.11912/2653/Trabajo\%20de\% 20Grado-Juan $\% 20$ Bernardo\%20Tasc\%C3\%B3n\%200.pdf?sequence=1

Torres, M A., Uribe, J. C. y Cortés, F. A. (2011). Naturaleza jurídica en Colombia de la asistencia en viaje internacional. Chía: Universidad de la Sabana. Forum Especialización en Seguros y Seguridad Social. Recuperado de https://intellectum.unisabana.edu.co/bitstream/handle/10818/3826/Miryam\%20Aide \%20Torres\%20Gonz\%C3\%A1lez.pdf?sequence=1

Vigil, A. (2016). El contrato de seguro y la actividad aseguradora en Cuba. Revista Actualidad Jurídica Iberoamericana. (5), 114-149. 


\section{CAPÍTULO II CARACTERIZACIÓN DE LOS DERECHOS DEL CONSUMIDOR FINANCIERO EN EL MARCO DEL CONTRATO DE SEGURO VIDA GRUPO DEUDORES EN COLOMBIA}

\section{Resumen}

Los procedimientos legales de protección de los derechos del consumidor financiero se instituyen como la herramienta más eficaz para resolver los conflictos jurídicos presentes en los contratos de seguro de vida grupo deudores. Sobre este criterio, el presente capítulo se encamina en la caracterización de los derechos del consumidor financiero, pero orientado hacia el contrato de seguro, más particularmente en el seguro de vida grupo deudores. El desarrollo de este capítulo contempla el estudio de los fundamentos teórico-conceptuales y teóricos de la institución del consumidor, hasta consolidar unas herramientas jurídicas que permitan fortalecer los derechos de los consumidores financieros en los contratos de seguros de vida grupo deudores.

\subsection{Introducción}

El objetivo del presente capítulo es desarrollar el análisis teórico-conceptual y jurídico del consumidor financiero en el marco de los contratos de seguro de vida grupo deudores, para lo cual se establece en un principio qué se entiende por sistema financiero, para continuar después con el consumidor financiero en cuanto a las diversas definiciones dadas por la doctrina, la ley y la propia jurisprudencia.

Enseguida se aborda el marco legal del consumidor financiero destacando entre las leyes más relevantes la Ley 1328 de 2009, que corresponde al régimen legal del consumidor financiero, y la Ley 1480 de 2011 relativa al Estatuto del Consumidor. Estos elementos 
consolidan el marco legal colombiano, el cual se complementa con las medidas tomadas por la Superintendencia Financiera de Colombia a través de las circulares externas para delimitar con claridad los mecanismos legales con los que cuentan los consumidores financieros.

En ese sentido, se identifican enseguida los derechos y obligaciones del consumidor financiero, estableciendo cómo la vía jurídica ha establecido un marco sistemático de derechos, en tanto que el nivel de obligaciones ha quedado en manos de las entidades vigiladas. Finalmente, en el último apartado se proponen las herramientas jurídicas que se deben implementar para fortalecer los derechos del consumidor financiero y, a su vez, disminuir los altos niveles de asimetría presentes entre la posición dominante de la aseguradora y el deudor o asegurado.

\subsection{Consumidor financiero (definición, tipos, derechos, obligaciones) en el marco de los contratos de seguro en Colombia}

\subsubsection{Sistema financiero}

Antes de entrar a definir qué se entiende por consumidor financiero, es menester asumir el concepto de sistema financiero por la trascendencia que tiene en el presente objeto de estudio. En ese sentido, Paolantonio (2010a) citando a Nieto, plantea la siguiente definición:

El sistema financiero es (...) el conjunto de intermediarios, mercados e instituciones que enlazan las decisiones de ahorro con las de gasto, esto es, que transfieren renta desde unidades excedentes hasta las deficitarias; es por lo tanto el conjunto de fuerzas de oferta y demanda de ahorro, así como los canales e instrumentos, jurídicos y económicos, humanos, materiales y técnicos, a través de los cuales se potencia el 
ahorro y se permite un equilibrio eficiente entre tales fuerzas (Paolantonio, 2010a, p. 262)

Se entiende entonces cómo el sistema financiero tiene que ver con aquél conjunto de fuerzas e intereses orientados a la obtención de un excedente en la prestación de sus servicios financieros. En un ámbito similar Chiriboga (2010) recalca que un sistema financiero es aquél conjunto de instituciones financieras privadas, que bajo una denominación de compañía anónima realiza "transacciones monetarias y no monetarias (...) permite proveer de servicios de pago, movilizar el ahorro y asignar el crédito, además de limitar, valorar, aunar e intercambiar los riesgos resultantes de esas actividades" (p. 18).

Esta definición se torna más completa, ya que incluye no sólo las instituciones financieras básicas, como los bancos, sino también aquellas entidades que ofrecen los servicios financieros, como es el caso de las compañías aseguradoras. No obstante, se plantea que esta definición se queda corta, en tanto se olvida que parte del sistema financiero son las entidades que lo vigilan, ya que no tienen la autonomía total en el manejo de los negocios, sino que se encuentran supervisadas por un organismo estatal, siendo en el caso de Colombia la Superintendencia Financiera (Blanco, 2008).

En esa línea, Hernández y Parro (2004) identifican cinco funciones básicas que tiene el sistema financiero, en el que su interés está dado por una reducción en los costos de las transacciones, en el manejo eficiente de la información y hacer efectivos los contratos en el sector:

- Producción de información ex ante acerca de las posibles inversiones y asignaciones de capital. 
- Monitoreo de las inversiones realizadas y los gobiernos corporativos.

- Comercialización, diversificación y administración de riesgos.

- $\quad$ Movilización de ahorros.

- $\quad$ Provisión de medios de pagos para facilitar el intercambio de bienes y servicios (Hernández y Parro, 2004, p. 3).

Estas funciones ponen de relieve que un sistema financiero no se concentra en el ámbito del ahorro, sino que lleva a cabo diversos tipos de desempeño, como manejo de información, medios de pago y vigilancia en sus movimientos financieros, pero siempre, se recalca, bajo la supervisión de una entidad estatal, que debe verificar que no se extralimiten en sus funciones o que lleven a cabo malas prácticas (Pecho, 2013).

Estas características llevan a afirmar a Gutiérrez (2008) que el sistema financiero es la expresión más viva del capitalismo moderno, en el que el sistema financiero asumió su mayor poder, coadyuvado por el mejoramiento de las tecnologías de la información y de las comunicaciones, lo que permitió que se fortalecieran bajo el fenómeno de la globalización.

Estos tres elementos integrados: entidades financieras, tecnologías de la información y de las comunicaciones y la globalización, han generado en las últimas décadas un proceso dependencia de los Estados hacia los movimientos y mercados financieros internacionales, ya que estos pueden socavar las economías y con ello, la misma democracia, que se hace más vulnerable en las economías en desarrollo por su alto nivel de dependencia del capital extranjero (Daher y Moreno, 2016, Medina y Vargas, 2013)

En síntesis, se comparte la postura de Maudos y Fernández (2006) respecto al sistema financiero que, tal como está actualmente operando en Colombia y en el mundo en general, 
se constituye como un fenómeno que origina una posición dominante hacia los usuarios y clientes. De igual manera, esto se pone en evidencia no sólo en el ámbito particular del consumidor como tal, sino de las mismas instituciones del Estado, incluyendo los organismos de vigilancia y control de la actividad financiera, que son los encargados de amparar a la parte débil de la negociación: el consumidor (Barbosa, Medina y Vargas, 2014).

\subsubsection{Definición de consumidor financiero}

De acuerdo con la Ley 1328 de 2009, se define en su artículo $2^{\circ}$ al consumidor financiero como "todo cliente usuario o cliente potencial de las entidades vigiladas". Esta definición legal permite comprender inicialmente que el consumidor tiene una doble condición; como usuario y como cliente.

Esto trae importantes consecuencias para el sector financiero, en la medida que cualquier persona que, de una u otra forma, utilice los servicios financieros, así sea mínimamente, tiene per se la calidad de consumidor financiero, luego tiene la protección y amparo del Estado frente a las actuaciones de los proveedores de servicios financieros. Esto implicaría también la exigencia para que estas compañías brinden la información necesaria a sus usuarios o clientes, la cual debe tener la condición de ser cierta, clara, oportuna y suficiente (Cano, Esguerra, García, Rueda y Velasco, 2014).

Profundizando en la noción, desde el punto de vista legal, se toma en cuenta el Decreto 2555 de 2010, en el que se define al consumidor financiero de la siguiente manera:

Se entiende por consumidor financiero, los clientes y usuarios de las entidades vigiladas, los inversionistas de los productos ofrecidos a través de los mercados de activos financieros, los asegurados, los afiliados al régimen general de pensiones, así 
como todos aquellos que determine la ley o el Gobierno Nacional (Decreto 4327, 2005, art. 80).

De otro lado, desde la perspectiva de la Corte Constitucional, mediante Sentencia C909 de 2012, la noción de consumidor financiero presenta un carácter poliédrico, ya que supone la convergencia de diversos intereses sustanciales, siendo entre otros, calidad de los bienes como de los servicios que ofrecen las entidades financieras; también de carácter procesal por los mecanismos que tiene el consumidor para demandar de estas entidades las garantías que la constitución y las leyes le determinan, pero también ante la posibilidad de una indemnización en caso de que se ocasionen perjuicios y; finalmente, en el nivel de participación de los diversos poderes públicos que tiene el Estado en la protección de sus derechos:

Los poderes públicos, en las instancias de producción y aplicación del derecho, en la permanente búsqueda del consenso que es característica del Estado social y misión de sus órganos, deben materializar como elemento del interés público que ha de prevalecer, el de la adecuada defensa del consumidor, para lo cual deben habilitarse procedimientos y mecanismos de participación y de impugnación con el fin de que sus intereses sean debidamente tutelados (Corte Constitucional, Sentencia C-909, 2012).

Asimismo, desde la doctrina se plantea que dicha noción se debe comprender desde una perspectiva jurídico-económica en cuyo centro se encuentran personas concretas con intereses concretos en relación con la calidad del servicio financiero, es decir, desde el punto de vista constitucional, que el consumidor sea tratado con dignidad humana (Viguria, 2013). 
Ahondando, Cuellar (2012) expresa que la protección del consumidor se debe brindar desde varios escenarios, ya que se encuentra en una situación de vulnerabilidad frente al poder de dominio de las entidades financieras:

(i) Entender mejor la relación existente entre un régimen fuerte de protección al consumidor y la estabilidad financiera; (ii) fortalecer los vínculos entre protección e inclusión financiera, entendiendo que las experiencias $-\mathrm{y}$ necesidad de productosde los usuarios ubicados en la base de la pirámide de ingresos difieren de aquellos del resto del mercado; y (iii) impulsar técnicas que contribuyan al desarrollo de las capacidades financieras de los consumidores (Cuéllar, 2012, p. 1).

\subsubsection{Marco legal del consumidor financiero}

El marco legal sobre el cual se sustentan los derechos del consumidor en Colombia se encuentra en la Constitución Política de 1991, en sus artículos 78, 150, 189 y 334; así como en la Ley 1328 de 2009, relativo al régimen de protección al consumidor, y en la Ley 1480 de 2011 o Estatuto del Consumidor. En cuanto a la Carta Política, el art. 334 es claro en subrayar que la dirección de la economía se encuentra a cargo del Estado, pero, igualmente en el artículo 150, numeral 19, establece que una de las funciones del poder legislativo es la de "Regular las actividades financiera, bursátil, aseguradora y cualquiera otra relacionada con el manejo, aprovechamiento e inversión de los recursos captados del público”.

De igual manera, en el artículo 189 de la misma Constitución otorga poder al ejecutivo para que ejerza la función de “inspección, vigilancia y control sobre las personas que realicen actividades financiera, bursátil, aseguradora y cualquier otra relacionada con el manejo, aprovechamiento o inversión de recursos captados del público”. 
Asimismo, la Carta Política, mediante el artículo 78, pone relevancia a los derechos de los consumidores, al establecer que la ley será la encargada de regular el nivel de calidad y control de los bienes y servicios que son ofrecidos a la comunidad, pero igualmente pone su interés en la necesidad de que exista participación de las organizaciones de consumidores respecto a la configuración de leyes relativas a estos. Finalmente, determina que la ley establecerá el nivel de responsabilidad de quienes son responsables de la producción, distribución y comercialización de bienes y servicios (Chamié, 2013).

Es entonces desde estas funciones del legislador y del ejecutivo que los derechos del consumidor adquieren relevancia, en la medida que se trazan los elementos constitucionales para una política pública basada en los derechos colectivos de los consumidores (Bustos, 2016). Sobre esta base constitucional es que se promulgó el Estatuto del Consumidor, con el objetivo de "proteger, promover y garantizar la efectividad y el libre ejercicio de los derechos de los consumidores, así como amparar el respeto a su dignidad y a sus intereses económicos” (Estatuto del Consumidor, art. $1^{\circ}$ ).

En este ámbito de protección y promoción, se determina también en el mismo artículo que el amparo será especial en los siguientes aspectos: protección frente a riesgos de la salud y seguridad, acceso a una información adecuada por parte de los consumidores, educación del consumidor, capacidad para crear organizaciones de consumidores y su respectiva participación en los proyectos legislativos y protección especial a la infancia y la adolescencia ( Quintero, 2014).

Asimismo, en relación con el consumidor financiero, el Estatuto en mención aborda un capítulo dedicado a las facultades jurisdiccionales que tiene la Superintendencia Financiera, señalando al respecto: 
Los consumidores financieros de las entidades vigiladas por la Superintendencia Financiera de Colombia podrán a su elección someter a conocimiento de esa autoridad, los asuntos contenciosos que se susciten entre ellos y las entidades vigiladas sobre las materias a que se refiere el presente artículo para que sean fallados en derecho, con carácter definitivo y con las facultades propias de un juez (Estatuto del Consumidor, 2011, art. $8^{\circ}$ ).

Se añade igualmente en este artículo, que en el marco de dichas facultades jurisdiccionales de la Superintendencia Financiera, ésta podrá conocer aquellas controversias que se establezcan entre las entidades financieras y los consumidores financieros, sobre todo en el cumplimiento de las obligaciones contractuales (Betancourt, 2014). Pero, se advierte igualmente que esta Superintendencia no puede conocer asuntos que tengan que ser sometidos a un proceso ejecutivo, así como tampoco aquellos relativos a procesos laborales.

Finalmente, para Patiño (2012) en el artículo $2^{\circ}$ de la Ley ibídem se precisa que estas normas giran a todas las relaciones de consumo, salvo aquellas leyes que versen sobre aspectos especiales, de ahí es que toma importancia la Ley 1328 de 2009, en el que se fija el régimen para la protección del consumidor financiero, siendo uno de sus elementos esenciales la definición de los principios que deben regir entre este y las entidades financieras vigiladas por la Superintendencia Financiera, siendo principalmente los siguientes:

- Debida diligencia: El primero es el principio de debida diligencia, el cual se plantea que la misma se debe dar no sólo en la oferta de sus productos, sino también en la prestación de los servicios, pero siempre sobre la base de que los consumidores "reciba la información y/o la atención debida y respetuosa en desarrollo de las relaciones que 
establezcan con aquellas, y en general, en el desenvolvimiento normal de sus operaciones" (Ley 1328 de 2009, art. $3^{\circ}$ ).

En el mismo artículo se precisa que esta debida diligencia debe conducir a la satisfacción de las necesidades de los consumidores, ello conforme a la oferta, el compromiso y las obligaciones acordadas

- Libertad de elección: se establece que tanto las entidades vigiladas como los consumidores financieros tienen la autonomía para escoger de forma libre a sus contrapartes al momento de celebrar los contratos. Asimismo, subraya que cualquier negativa frente a los servicios o productos ofrecidos deberá justificarse en debida forma a los consumidores financieros.

- Transparencia e información cierta, suficiente y oportuna: este principio plantea que las entidades tienen la responsabilidad de suministrar la debida información a los consumidores financieros, tanto de los productos como de los servicios financieros. Esto con el objeto de que "los consumidores financieros conozcan adecuadamente sus derechos, obligaciones y los costos en las relaciones que establecen con las entidades vigiladas”.

Es claro que el deber de información adquiere mucha importancia ya que esto implica que se puedan superar la asimetría entre el conocimiento que tienen las entidades financieras y los usuarios o asegurados.

El derecho a la información tiene por finalidad que el consumidor adquiera el conocimiento necesario del producto o servicio para poder dar su consentimiento26, de modo que cuando exprese su voluntad esté al tanto de las cualidades, las ausencias y los riesgos del bien o servicio al que está accediendo, de las condiciones del contrato que está pactando y de los mecanismos de protección que le otorga el ordenamiento 
jurídico. La información permite que se reduzca el desequilibrio existente entre el consumidor y el empresario (Saavedra, 2012, p. 155)

Esta necesidad de superar el desequilibro contractual en materia de información es uno de los puntos álgidos en materia de seguros, en tanto el consumidor financiero siempre tiene que circunscribirse a las cláusulas establecidas por estas compañías, pues de lo contrario no podrán asegurar el bien o servicio solicitado.

Al respecto Morgestein (2014) subraya que la información corresponde a aquél conocimiento que es suministrado de forma obligatoria por las partes contratantes, en el entendido que no sólo está en cabeza del asegurador, sino también del tomador y el asegurado.

De este deber surgen tres elementos clasificatorios: obligación de informar sobre condiciones, alcance y compromisos al adquirir el producto; deber de orientación e información al cliente $\mathrm{y}$; por último, advertir sobre los peligros materiales o jurídicos (Namén, Bonilla, Pabón y Uribe, 2009).

Aunado a estos elementos, es dable recordar que la Ley 1480 de 2011, estableció en los artículo 23 y 24 las características mínimas relativas a la información: veraz y comprobable (datos e información que sea real y verídica para no inducir a error al consumidor); adecuada, suficiente y completa (pleno conocimiento de beneficios pero también de riesgos); clara, comprensible y entendible (se deba ajustar al consumidor promedio y conforme a las condiciones del mercado); oportuna (la información debe estar plasmada desde la etapa precontractual) (Muñoz, 2012). 
- Responsabilidad de las entidades vigiladas en el trámite de quejas: debe existir un alto nivel de eficiencia por parte de las entidades financieras vigiladas para que atiendan diligentemente las quejas y reclamos de los consumidores financieros. Ello implica no sólo solucionar el asunto, sino también identificar las causas que lo originaron y desarrollar acciones para solucionar de fondo el problema y evitar que nuevos casos se presenten.

- Manejo adecuado de los conflictos de interés: este es otro de los aspectos esenciales sobre el cual es menester detenerse un poco. De acuerdo con el artículo $3^{\circ}$ de la Ley 1328 de 2009, este principio exige que las entidades vigiladas atiendan y administren de forma clara aquellos conflictos de interés propios, como los que se puedan presentar entre consumidores financieros.

Este manejo adecuado de los conflictos de interés se exigen de igual forma en el Decreto 2555 de 2010, ya que queda expresamente claro a las compañías aseguradoras de vida "velar porque siempre prevalezca el interés de los consumidores financieros" (art. 2.6.10.1.2). En ese sentido, es válido recordar la definición aportada en este decreto:

Se entiende por conflicto de interés la situación en virtud de la cual una persona en razón de su actividad se enfrenta a distintas alternativas de conducta con relación a intereses incompatibles, ninguno de los cuales puede privilegiar en atención a sus obligaciones legales o contractuales (Decreto 2555, 2010, art. 2.11.4.2.1)

Este conflicto de interés supone identificar tres tipos de conductas que son generadoras de conflicto de interés: utilidad propia y la de un cliente, de un tercero vinculado al agente y utilidad de una operación y la transparencia del mercado. De estas conductas, es relevante tomar en cuenta la relativa a la utilidad propia, ya que esta situación se puede presentar en 
los casos en los cuales la entidad crediticia, en calidad de tomadora, asegura al deudor en una aseguradora que se encuentra en el mismo grupo económico v. gr. Banco DaviviendaSeguros o Banco BBVA - Seguros BBVA.

Si bien el tema de los conflictos de interés no fue tratado en la jurisprudencia ya analizada en el acápite anterior, tal como se mencionó en las primeras conclusiones, sí requiere de un análisis jurídico integral, pues no queda por fuera de duda, que una negativa de la aseguradora, acompañada de un respaldo del banco, siendo ambos perteneciente al mismo grupo económico, genera sin duda alguna, conflicto de interés, ya que se está ante un beneficio o utilidad propia, así tengan una personería jurídica diferente.

- Educación para el consumidor financiero: de acuerdo con este principio, se exige a todos las entidades responsables o relacionadas con el sector financiero (entidades vigiladas, asociaciones de consumidores, entidades de supervisión y vigilancia, entre otras) que lleven a cabo programas o proyectos orientados a la educación del consumidor financiero. Esta educación debe abordar aspectos específicos como productos y servicios financieros, naturaleza de los mercados en los que actúan, instituciones autorizadas y los mecanismos de defensa con los que cuenta el consumidor financiero.

A partir de estos principios, la Ley 1328 define en igual forma los derechos y obligaciones de los consumidores financieros. En virtud de la importancia que se genera en el tratamiento de estos dos elementos, se considera necesario abordarlos en apartados diferentes, tal como a continuación se realiza.

\subsubsection{Derechos del consumidor financiero}

Inicialmente, el artículo $5^{\circ}$ de la Ley 1328 de 2009 hace explícito los derechos de los consumidores financieros, siendo los más relevantes: desarrollo del principio de debida 
diligencia; derecho a la información transparente en la prestación del servicio; derecho a recibir una adecuada educación financiera; el derecho a presentar peticiones, solicitudes, quejas o reclamos; y los demás establecidos por la ley.

En relación con el derecho a la debida diligencia, se expresa por parte de Arévalo y Rivera (2013) que esta debe ser asumida de forma integral por todos y cada uno de los funcionarios que prestan los servicios financieros, ya que todos tienen la responsabilidad de que las solicitudes de los usuarios y clientes se tramiten en el menor tiempo posible, pero, sobre todo, que se dé una respuesta efectiva, así sea negativa, a dichas solicitudes.

Ello, debido a que una de las quejas más frecuentes de los consumidores financieros es la falta de una cultura de servicio de las entidades financieras, que se materializan en un desgreño administrativo para atender sus inquietudes, tal como se muestra en las estadísticas de quejas recibidas por la Superintendencia Financiera a 2016

Tabla 2. Quejas recibidas por la Superintendencia Financiera de Colombia en el ramo seguros año 2016

\begin{tabular}{|l|c|}
\hline \multicolumn{1}{|c|}{ Compañía aseguradora } & $\begin{array}{c}\text { Número } \\
\text { de quejas }\end{array}$ \\
\hline Allianz Seguros S.A. & 8.285 \\
\hline Ace Seguros S.A. & 590 \\
\hline Seguros Colpatria S.A. & 14.476 \\
\hline ECO Seguros S.A. & 3 \\
\hline Compañía Aseguradora de Fianzas S.A. & 131 \\
\hline QBE Seguros S.A. & 109 \\
\hline Generali Colombia Seguros Generales S.A. & 2.771 \\
\hline Royal \& Sun Alliance Seguros (Colombia) & 418 \\
\hline Compañía Mundial de Seguros S.A. & 680 \\
\hline Seguros Generales Suramericana S.A. & 19.626 \\
\hline Chubb de Colombia Compañía de Seguros & 160 \\
\hline AIG Seguros Colombia S.A. & 1.567 \\
\hline La Previsora S.A. Compañía de Seguros & 2.269 \\
\hline Seguros Alfa S.A. & 811 \\
\hline Mapfre Seguros Generales de Colombia S.A. & 3.956 \\
\hline
\end{tabular}




\begin{tabular}{|l|c|}
\hline Seguros Comerciales Bolívar S.A. & 8.952 \\
\hline Seguros del Estado S.A. & 489 \\
\hline Segurexpo de Colombia S.A. & 5 \\
\hline Liberty Seguros S.A. & 3.581 \\
\hline BBVA Seguros Colombia S.A. & 3.236 \\
\hline Cardif Colombia Seguros Generales S.A. & 3.859 \\
\hline Cardinal Compañía de Seguros S.A. & 3 \\
\hline Berkley International Seguros Colombia S.A. & 2 \\
\hline TOTAL QUEJAS & 75.979 \\
\hline
\end{tabular}

Fuente: Superintendencia Financiera de Colombia, 2017.

Como bien puede observarse, las mayores quejas corresponden a Seguros Generales Suramericana S. A. $(25,83 \%)$ seguido de Seguros Colpatria S. A. con un 18,1\%. Estos resultados muestran igualmente cómo el sector asegurador ocupa el tercer lugar en quejas, únicamente superado por el sector bancario (765.782 quejas) y el de las compañías de financiamiento y leasing (177.842 quejas) (Superintendencia Financiera de Colombia, 2017).

Esta falta de diligencia se observa igualmente en el ramo de seguro de vida grupo deudores (Ver tabla 3).

Tabla 3. Quejas recibidas por la Superintendencia Financiera de Colombia año 2014

\begin{tabular}{|l|c|}
\hline \multicolumn{1}{|c|}{ Motivos productos } & $\begin{array}{c}\text { Seguro de vida } \\
\text { grupo }\end{array}$ \\
\hline Suplantación presunta de persona & 1 \\
\hline Vinculación presuntamente fraudulenta & 1 \\
\hline Tarifas & 18 \\
\hline Información sujeta a reserva & 25 \\
\hline Objeción o negativa para atender el siniestro & 365 \\
\hline Aspectos contractuales (Incumplimiento y/o modificación) & 1.479 \\
\hline Mora en el pago o en el reconocimiento & 2.273 \\
\hline Indebida atención al consumidor financiero-servicio & 3.356 \\
\hline Inadecuado suministro de información en la vinculación & 10.238 \\
\hline
\end{tabular}




\begin{tabular}{|l|l}
\hline TOTAL GENERAL & 17.756 \\
\hline
\end{tabular}

Fuente: Elaboración propia de información de la Superintendencia Financiera de Colombia (2017)

Conforme a los datos reflejados por la Superintendencia Financiera, se pone en evidencia la falta de la debida diligencia en las entidades financieras, sobre todo la relacionada con el inadecuado suministro de información $(58,17 \%)$ así como en la indebida atención al consumidor $(18,9 \%)$.

Estos datos reportados por la Superintendencia Financiera llevan igualmente al análisis del derecho a la transparencia en la información sobre la prestación de los servicios de las entidades financieras. Para Bernal (2015) es evidente que en el cumplimiento de los derechos del consumidor financiero es esencial que dicha información sea clara, ya que es un factor determinante en el curso que puedan tener los negocios jurídicos que se pacten.

Con el fin de ofrecer un servicio que satisfaga las necesidades de los consumidores financieros las entidades vigiladas deben informar quien es el Consumidor Financiero, ofrecer productos y servicios debidamente, con la seguridad requerida, además de dar toda la información solicitada y contar con un Sistema de atención al Consumidor Financiero, evitando conductas inadecuadas contractuales con contratos claros que incluya términos, condiciones, derechos, obligaciones, tasas, precios y tarifas (Bernal, 2015, p. 15).

En el mismo sentido se presenta el estudio de Blanco (2012) quien sostiene que el suministro de la información le permitirá al consumidor financiero tomar una decisión responsable, puesto que si no se hace así, es posible que se origine una falta de confianza 
frente a si la aseguradora le cubrirá los riesgos aparentemente pactados en el contrato, máxime cuando la información relativa a seguros es compleja, luego se requiere que la información no se limite únicamente a los formatos y modelos preestablecidos y colocados en la web, sino también personalmente, en el momento de iniciarse diálogos directos asegurado-aseguradora, orientados al interés por contratar un seguro.

Este derecho a la información tiene su incidencia también en el contrato de seguro, tal como lo precia Díaz (2012) quien subraya elementos claves a tener en cuenta en las diversas fases de dicho contrato. En ese sentido, en la etapa precontractual recuerda que las aseguradoras deben entregar anticipadamente el clausulado del contrato, explicando de forma detenida la cobertura, exclusiones y garantías; todo ello soportado en el art. 37 de la Ley 1328 de 2009.

Es claro para Pinzón (2016) que si estos elementos no son especificados, no tanto en el contrato, sino en los mecanismos utilizados para informar al tomador o asegurado, se podrá tornar ineficaz dicho contrato. Es por ello que Díaz (2012) plantee aplicar el criterio de razonabilidad en los siguientes términos:

El deber de información a cargo del asegurador hay que entenderlo en el contexto de las respectivas operaciones, con criterio de razonabilidad, pues no es lo mismo un contrato de seguro masivo, a una póliza de todo riesgo para un complejo industrial. Si desconocemos esta realidad seguramente pondremos en peligro programas de microseguros de primas muy bajas que, además de las particularidades de su distribución, podrían tornarse inviables en términos económicos y operativos, generando privación de mecanismos de amparo para la población, en lugar de bienestar al consumidor (Díaz, 2012, p. 79). 
Al respecto, se proponen varias alternativas para materializar la información requerida por el tomador o asegurado, aparte de la suministrada en la web. Entre estas se encuentra la labor que pueden ejercer los intermediarios de seguros, una cartilla o folleto que explique claramente, hasta con ejemplos, sobre la descripción de los riesgos, coberturas y exclusiones y; como tercera opción, la creación por parte de la compañía aseguradora de un equipo de asesores virtuales y presenciales que, previo a la firma del contrato, le hagan saber no sólo las bondades de cada seguro, sino también sus limitaciones y exigencias legales que deben cumplir los tomadores o asegurados.

Asimismo, frente al derecho a una adecuada educación financiera, basta señalar que no tenía la relevancia necesaria, de ahí que sólo hasta 2009, en los literales $o$ y $p$ de la Ley 1328 de 2009, se vinieron a sentar las bases jurídicas para el fomento y promoción de la educación financiera al consumidor:

o) Que las entidades vigiladas, las asociaciones gremiales, las asociaciones de consumidores debidamente reconocidos y las autoridades que ejercen la intervención del Estado en el sector financiero, implementen mecanismos encaminados a lograr una adecuada educación sobre los productos, servicios y derechos del consumidor financiero.

p) Incentivar la adecuada participación de las asociaciones de Consumidores Financieros en la formulación de las disposiciones que los afecten (Ley 1328 de 2009, art. 23)

Esta determinación es reafirmada por la Superintendencia Financiera (2010) que destacó la necesidad de llevar a cabo actividades de educación financiera, materializándose puntualmente en la página web de la Superintendencia Financiera, en el que se encuentran 
enlaces de relevancia para el consumidor financiero como simulador de conversión de tasas de interés, preguntas frecuentes, defensor del cliente, decálogo sobre pautas de prevención, normas destacadas sobre protección al consumidor, espacio de participación ciudadana y punto de contacto de la entidad.

Estas actividades están orientadas a la formación de una cultura del consumidor, pero se lamenta que las mismas se enfoquen casi exclusivamente a la página web, lo que sin duda no es eficiente, puesto que se excluyen a millones de ciudadanos que todavía no tienen acceso a estos niveles virtuales y, menos en hábitos de lectura de páginas virtuales. En ese sentido, es menester que la Superintendencia Financiera destine recursos para fortalecer y materializar una educación financiera eficaz y acorde a las necesidades y limitaciones de los consumidores financieros.

Finalmente, en lo relacionado con el derecho a presentar peticiones, solicitudes, quejas o reclamos, como bien se ha señalado, las entidades vigiladas cuentan con un defensor del consumidor, que es la persona encargada de ser el mediador intermediario entre el consumidor y la entidad financiera. Valga decir, que esta figura, si bien está consolidada en la ley, pierde peso en la medida que es sólo un formalismo, que inclusive se puede omitir, pues el consumidor financiero puede acudir directamente a la Superintendencia Financiera de Colombia para formular su respectiva queja (Moreno, 2014)

Mediante las circulares externas mencionadas, el órgano de vigilancia y control ordena a los defensores del consumidor financiero revisar los contratos de las vigiladas y remitir a la Junta Directiva de la respectiva entidad, o al órgano que haga sus veces, con copia a esta Superintendencia, un informe detallado de todas las cláusulas y prácticas abusivas identificadas (Moreno, 2014, p. 340). 
Aun así, frente a estas limitaciones Barrero (2016) recuerda que el defensor del consumidor puede asumir también el papel de conciliador como mecanismo autocompositivo, ya que se estaría promoviendo la resolución de un conflicto, evitando con ello que se lleguen a procesos más complejos y duraderos, en donde seguramente la persona más afectada será el deudor o el tomador.

Profundizando, Vilela (2012) subraya que en materia de quejas y reclamos, el sistema financiero, especialmente el bancario, es el que más presenta conflictividad, generando como principal consecuencia, la afectación de los derechos del consumidor financiero, de ahí que se propenda por superar aspectos tales como las cláusulas abusivas, que se desarrollan bajo el poder de dominio que tienen estas entidades, a lo que se suma ciertas facultades arbitrarias, pese a encontrarse bajo la vigilancia permanente de la Superintendencia Financiera.

De otro lado, además de los derechos ya mencionados, el artículo $6^{\circ}$ de la Ley 1328 de 2009 establece expresamente unas prácticas de protección que pueden ejercer directamente los consumidores financieros, que dada su importancia, se mencionan a continuación:

a) Cerciorarse si la entidad con la cual desean contratar o utilizar los productos o servicios se encuentre autorizada y vigilada por la Superintendencia Financiera de Colombia.

b) Informarse sobre los productos o servicios que piensa adquirir o emplear, indagando sobre las condiciones generales de la operación; es decir, los derechos, obligaciones, costos, exclusiones y restricciones aplicables al producto o servicio, 
exigiendo las explicaciones verbales y escritas necesarias, precisas y suficientes que le posibiliten la toma de decisiones informadas.

c) Observar las instrucciones y recomendaciones que imparta la entidad vigilada sobre el manejo de productos o servicios financieros.

d) Revisar los términos y condiciones del respectivo contrato y sus anexos, así como conservar las copias que se le suministren de dichos documentos.

e) Informarse sobre los órganos y medios de que dispone la entidad para presentar peticiones, solicitudes, quejas o reclamos.

f) Obtener una respuesta oportuna a cada solicitud de producto o servicio (Ley 1328, 2009, art. $6^{\circ}$.

Añade enseguida el legislador que el hecho de que no se han efectivas este tipo de prácticas, no significa que pierdan o se les desconozcan sus derechos. Ahora, al hacer un examen sobre estas prácticas, se encuentra que son elementos que ya han sido tratados anteriormente, sólo que se ubican como actividades que no requieren de una intermediación, sino que los puede ejercer directamente el consumidor financiero.

\subsubsection{Obligaciones del consumidor financiero}

Al indagar sobre las obligaciones del consumidor financiero, se evidencia que tanto en la Ley 1328 de 2009, correspondiente al régimen del consumidor financiero, como la Ley 1480 de 2011, estatuto del consumidor, no se encuentran de forma expresa algún tipo de obligación, pero sí hacen, sobre todo la primera ley, es establecer un significativo número de obligaciones a las entidades vigiladas. 
No obstante, algunas entidades vigiladas suelen incluir en sus portafolios virtuales las obligaciones atinentes a los tomadores o asegurados en los siguientes aspectos:

- Mantener el estado del riesgo y notificar a la aseguradora aquellos cambios no previsibles que sobrevengan a la firma del contrato de seguro (no menor de 10 días a la modificación del riesgo).

- Cumplir con las garantías.

- Pagar la prima.

- Declarar el estado del riesgo e informar sobre modificaciones. Esta declaración se debe hacer bajo los criterios establecidos en el cuestionario que es suministrado por la aseguradora (Acegroup, 2017).

De la misma manera, establecen una serie de obligaciones a los asegurados:

- $\quad$ Cerciorarse que la entidad aseguradora se encuentre autorizada y vigilada.

- Informarse sobre las características de los productos y servicios (derechos, obligaciones, costos, exclusiones, restricciones), así como de los órganos y medios para presentar peticiones, solicitudes, quejas o reclamos.

- Suministrar información cierta, suficiente y oportuna. Además, mantenerla actualizada.

- Observar las instrucciones y recomendaciones de la aseguradora (manejo de productos y servicios).

- Cumplir con todo lo pactado al momento de hacer el contrato de seguro.

- Revisar los términos y condiciones de los contratos. 
- Informar a la Superintendencia Financiera sobre entidades que no se encuentren legalmente autorizadas para prestar los servicios de seguros.

- Obrar de buena fe frente a los productores y proveedores y frente a las autoridades públicas (AON Corredores de Seguros, 2016).

- Evitar la extensión y propagación del siniestro y prever el salvamento de cosas que se encuentren aseguradas.

- $\quad$ Dar aviso dentro de los 3 días siguientes al salvamento.

- Informar si existen otros seguros respecto al mismo siniestro (indicando asegurador y monto asegurado)

- Demostrar la ocurrencia del siniestro.

- Permitir el ejercicio del derecho a subrogación (Global Seguros Colombia, 2017; Acegroup, 2017, Suramericana de Seguros, 2017).

Como bien se puede observar, la mayoría de las llamadas obligaciones planteadas por las aseguradoras son en realidad recomendaciones o deberes, ya que en caso de no cumplirse, los mismos no generan, en el marco de estas estipulaciones, consecuencias jurídicas para el tomador o el asegurado, o, por lo menos, no quedan expresas por parte de las aseguradoras, configurándose con ello lo que podría llamarse el incumplimiento del deber de informar a los consumidores en debida forma.

Inclusive, se puede señalar que existen algunos "deberes" que se quedan por fuera de un marco regulatorio de seguros, como es el caso de exigir que se obre de buena fe ante "productores, proveedores y frente a las autoridades públicas” (AON Corredores de Seguros, 2016). Estas expresiones se enmarcan por fuera de cualquier contexto negocial, puesto que es evidentemente violatoria de la Carta Política de 1991, ya que la misma establece en su 
artículo 83 que se debe presumir la buena fe en todas las gestiones, luego resulta exorbitante este tipo de "deberes".

\subsection{El asegurado como sujeto de las relaciones de consumo en los contratos de seguros en Colombia}

Al hablar del asegurado o tomador como sujeto de relaciones de consumo en los contratos de seguro, es importante entrar a indagar sobre la forma en que se conciben este tipo de contratos en el marco de la protección al consumidor.

En ese sentido, Palacios (2016) recuerda que la Ley 1328 de 2009, presenta una noción de los contratos de adhesión en los siguientes términos: "Son los contratos elaborados unilateralmente por la entidad vigilada y cuyas cláusulas y condiciones no pueden ser discutidas libre y previamente por los clientes, limitándose estos a expresar su aceptación o a rechazarlos en su integridad" (art. $\left.2^{\circ}\right)$.

De esta definición se identifican unos elementos que pueden contribuir a delimitar la relación con el derecho que tienen los consumidores. Uno de estos corresponde a la imposibilidad que se tiene de discutir términos y condiciones entre las partes, ya que las aseguradoras tienen la autonomía para elaborar estos contratos, aun cuando deba recordarse que sin embargo son vigilados por la Superintendencia Financiera de Colombia (Posada, 2015).

Otra característica que resulta relevante y surge como consecuencia de la anterior, es el hecho de que quien hace el contrato tiene una posición de dominio frente a su cocontratante, generando así limitaciones al consumidor financiero, en tanto no está en 
capacidad más allá de informarse del producto, coberturas, exigencias y limitaciones, pero nunca podrá interferir en cambiar las cláusulas generales.

Aun así, Lizama (2016) plantea que esta posición dominante no aplica en su totalidad a los tomadores, como es el caso de las entidades bancarias, las cuales, en el marco de los contratos de seguro vida grupo deudores, se encuentran en capacidad de ejercer algún tipo de incidencia para cambiar tales cláusulas, pero, como ya se vio en el anterior capítulo, la regla general aplicada a este tipo de seguros es que bancos y aseguradoras sean parte del mismo conglomerado económico, luego no entra a operar la adhesión como tal en los tomadores, sino en cabeza de los deudores, luego no es mucho lo que puedan esperar estos de los tomadores para hacer exigencias a las aseguradoras.

Como efecto de lo anterior, se evidencia que la parte débil (tomador o asegurado) no tiene mayor opción que aceptar las cláusulas en su totalidad, es decir en bloque, de suyo que en calidad de consumidor no puede modificarlas. En últimas, aceptar o rechazar la oferta de seguro, no hay mayores opciones. En ese sentido, López (2010) recuerda que existe una discusión en torno a si realmente aquí se estaría dando un acuerdo de voluntades. Quienes no lo están opinan de la siguiente manera:

El llamado contrato de adhesión (...) no es tal contrato, en vista que uno de los contratantes, el oferente, está emitiendo una voluntad reglamentaria; el otro ofertante, se encuentra en la imposibilidad de discutir los términos del contrato y acepta las condiciones preestablecidas o no hay tal operación jurídica, cuyo resultado dice el jurista, no es obra de dos voluntades (López, 2008, p. 2). 
Igualmente, Palacios (2016) recuerda cómo desde hace décadas se viene reclamando los altos niveles de asimetría en los contratos de adhesión, como es el contrato de seguro de vida grupo, ya que en estos casos se ve menguada la voluntad del adherente "frente al otro contratante que ostenta una posición dominante en cuanto que es un profesional en el contrato, que conoce sus intríngulis y además los administra” (p. 17).

No obstante, se recalca en la necesidad de no "satanizar" este tipo de contratos, en particular el de seguros, ya que los mismos se presentaron como una respuesta ante la necesidad de generar mayores niveles de producción de bienes, de ahí la necesidad de colocar mayores volúmenes de inventarios y, por ende, mayores recursos que fueran respaldados.

De otro lado, la Ley 1480 también contempla el tratamiento de los contratos de adhesión, especificando en su artículo $3^{\circ}$, numeral 1.6, que frente a este tipo de negocios, el consumidor será protegido ante posibles cláusulas abusivas. Aquí, se considera en principio, que es muy difícil que se puedan determinar este tipo arreglos contractuales, ya que para poder ofrecer algún tipo de contrato, las aseguradoras requieren de la autorización expresa de la Superintendencia Financiera para expedir todos y cada uno de los contratos, luego dichos modelos ya han pasado por el tamiz de esta entidad (López y Martelo, 2012).

De otro lado, es menester identificar también la figura del asegurado como sujeto de relaciones de consumo en los contratos de seguro, de ahí que sea dable señalar cuáles son esas disposiciones presentes en la legislación del consumidor que tienen notable incidencia en el contrato de seguro, como se hace a continuación:

- Derecho del consumidor de seguros a recibir una información cierta, suficiente y oportuna. Este derecho le permitirá conocer con claridad cuáles son los derechos y 
obligaciones y, en consonancia, podrá tomar la mejor decisión. Ahora, para que esto se presente, es imperativo no sólo que las aseguradoras elaboren pólizas con la suficiente claridad, sino que por parte de la Superintendencia Financiera de Colombia, se pueda exigir que en las mismas vaya anexo una información clara sobre los efectos de las cláusulas que mayor vulnerabilidad o efectos negativos pueda generar en el tomador y asegurado.

En síntesis, de lo que se trata es de arreglar el desequilibrio contractual tantas veces mencionado que se produce por el nivel de información de que disponen el productor (aseguradora) y el proveedor (intermediario de seguros), es decir con información calificada propia de quienes son profesionales en el contrato y de la otra (el tomador), quien por lo general carece de tal información especializada, o con la información mediana sobre el tema (Palacios, 2016, p. 25).

Se precisa entonces cómo la información, el suministro de información se convierte en uno de los imperativos que se requiere aplicar por parte de las aseguradoras, aspecto que realmente se encuentra apenas en una formalidad, en tanto estas entidades se limitan a poner la información en web, conforme a las normas legales y criterios de la Superintendencia Financiera, pero sin dar un paso más, es decir de hacer el esfuerzo de tener alternativas de información - formación al usuario, al consumidor financiero.

Es por ello que se requiere tomar en cuenta que la información no sólo se precisa al momento de cerrar el contrato, sino que debe estar en todas las fases (precontractual, ejecución, terminación). Se comparte la posición de Palacios (2016) quien recalca que la información debe ser cualificada, es decir que le permita dotar al consumidor financiero de verdaderas herramientas y elementos para que tome la mejor decisión para éste y, en segundo 
lugar, que se pueda ofrecer al tomador o asegurado un cuadro comparativo sobre las debilidades y fortalezas de los productos ofrecidos.

- $\quad$ Prohibición de publicidad engañosa. El tema de la publicidad engañosa se encuentra íntimamente relacionado con el deber que tienen las aseguradoras de informar claramente sobre los productos y servicios que prestan. Las consecuencias apuntarían a que el asegurado tomaría una decisión errónea, ya que la misma se basaría en una realidad distorsionada, luego los efectos jurídicos deberían conducir a la anulación de las cláusulas abusivas o, con mayor precisión a la anulación general del contrato.

Esta situación es bien compleja, ya que se entraría en un campo jurídico en el que normalmente el asegurador cuenta con el equipo profesional competente para afrontar esta problemática, en tanto que el tomador le tocaría recurrir a instancias judiciales a resolverlo, lo que demoraría o perjudicaría notablemente su calidad de vida (Vásquez, 2012).

- $\quad$ El asegurado debe recibir educación sobre los productos y servicios financieros. Como se ha venido reiterando en algunos apartes de este estudio, el tema de la educación financiera se convierte en uno de los elementos más débiles en la relación contractual entre aseguradora y asegurado, ya que la primera cuenta con años de experiencia, formación y capacidad financiera que la hace tener el poder dominante.

Ahora, cambiar esta asimetría es, tal vez, una utopía, ya que los consumidores no tienen un contacto permanente con este sector, sino que es una situación que se torna necesaria en algún momento de la vida, luego no le queda mayor alternativa que dejarse asesorar y aceptar la que pueda considerar la menos gravosa u onerosa. 
Aquí sí opera el sentido de la buena fe, es decir aplicar la buena fe empresarial e institucional (Ayala 2016), que se debe materializar en un catálogo de buenas prácticas de la industria aseguradora o, como se menciona en instituciones como Fasecolda (2014), la promoción de las buenas prácticas basados en la responsabilidad con el sector, lo que coadyuvará a generar mejores procesos de educación al consumidor, quien tendrá la certeza sobre qué producto en realidad está adquiriendo.

- Prohibición de incorporar cláusulas abusivas en las pólizas. Para Palacios (2016) no se puede partir de entrada que los contratos de seguro son cláusulas leoninas, vejatorias o exonerativas, puesto que sería entender que siempre va a existir un beneficio para una de las partes, pues resultaría del todo fuera de lugar, ya que muchas empresas y deudores se han beneficiado de este tipo de seguros.

Lo que sí queda claro es que el nivel de cualificación de la sociedad, así como los mecanismos de protección y, por supuesto, los fallos de la jurisprudencia, dejan entrever que el sector asegurador se debe adaptar a las nuevas condiciones que se plantean con el consumidor financiero, pero, a su vez, que cada vez éste último tiene un mayor conocimiento sobre sus derechos y las formas jurídicas para hacerlos efectivos, incluyendo la oposición a cláusulas abusivas:

De esa manera, la Sala explicó que las particularidades del contrato de seguro permiten al mismo desplegar sus efectos sobre el ámbito de protección a la libertad empresarial. No obstante, ello no quiere decir que se faculta al asegurador para ejercer un arbitrio contractual absoluto, pues la intervención estatal es necesaria para: (i) proteger otro principio constitucional, que es la igualdad de oportunidades; (ii) corregir imperfecciones de este mercado; (iii) permitir el acceso de estos bienes y 
servicios a todas las personas, especialmente 'aquellas que cuentan con menores ingresos o se hallan en condiciones de debilidad manifiesta' (Corte Constitucional, Sentencia T-240, 2016).

Ello genera entonces un ambiente que se puede considerar positivo y óptimo para que mejoren las relaciones contractuales de los seguros de vida grupo deudores, en tanto, se están construyendo principios y reglas jurídicas que están formando a unos y otros. Es en ese sentido que las llamadas cláusulas abusivas tendrán que desaparecer finalmente, bien por la revisión exhaustiva que haga la Superintendencia Financiera de Colombia o por vía judicial o jurisprudencial. A ello se puede llegar si se atienden con eficiencia los controles señalado por Echeverri, citada por Palacios (2016):

El primer control que se puede dar a las cláusulas abusivas es interpartes, es decir, a través propiamente de la autonomía de la voluntad cuando cada una de las partes al ser 'la mejor guardiana de sus propios intereses' no acepta la inclusión de una o de varias cláusulas dentro del contrato. Pero como ello no siempre es posible (...) se hace necesario el control 'desde afuera' por parte del Estado (Palacios, 2016, p. 30).

\subsection{Herramientas jurídicas a implementar para fortalecer los derechos del consumidor financiero en los contratos de seguro de vida grupo deudores}

“Deberán contar con Defensor del Consumidor Financiero de que trata este título los establecimientos de crédito (...) las entidades aseguradoras" (Decreto 2555, 2010, art. 2.34.2.1.1)

Para la atención de las quejas y reclamos bajo los siguientes procedimientos: 
- Presentar su queja y reclamo ante el Defensor del Consumidor con los datos personales, hechos, pretensiones concretas, quien tienen 3 días para la recepción.

- El Defensor del Consumidor da traslado de la queja o reclamo a la Superintendencia Financiera si el tema es de interés general, de lo contrario lo seguirá dentro de su ámbito de competencia. En esta fase el Defensor determina si es obligatoria la decisión y si es posible una audiencia de conciliación. Todo el trámite debe estar informándolo al consumidor. En caso de inadmisión de la queja, la comunicará igualmente al consumidor.

- El Defensor solicitará la información que requiera, tanto a la entidad involucrada como al consumidor de ser necesario, para el respectivo estudio de la queja o reclamo (8 días hábiles para recabar la información).

- El Defensor corre traslado a la entidad involucrada para que dé respuesta la consumidor (información y argumentos) (8 días hábiles para dar respuesta).

- El Defensor resuelve la queja, que debe ser motivada, clara y completa, informando a la entidad y al consumidor. Si es desfavorable a éste, el mismo podrá acudir a otro medio de protección, que sin duda, puede ser efectivamente la acción de tutela cuando se considere que están siendo vulnerados derechos fundamentales.

Durante todo este proceso el papel del Defensor del Consumidor, sobre todo en la decisión final, dependerá si la institución financiera, que si dentro de sus estatutos estableció la obligatoriedad y cumplimiento de las decisiones del Defensor, resultaría un procedimiento con grado de eficacia, pero si por el contrario, no se encuentra dentro de dichos estatutos 
dicha obligatoriedad, la entidad se abstendrá de actuar a favor de los intereses del consumidor. Esto es importante, puesto que se considera que no estaría operando una figura real en defensa del consumidor, en tanto dichas decisiones resultan inanes si no trascienden a la esfera de las decisiones a favor de la protección del consumidor, siendo con ello apenas una mera formalidad a cumplir.

No obstante, la norma es clara al precisar que el trámite ante el defensor del consumidor no es un requisito de procedibilidad, luego el consumidor financiero está en capacidad de acudir directamente a la Superintendencia Financiera para atender la queja o reclamo directamente con esta entidad pública.

“En desarrollo de sus funciones el Defensor del Consumidor Financiero no podrá determinar perjuicios, sanciones o indemnizaciones, salvo que estén determinadas por la Ley" (Decreto 2555, 2010, art. 2.34.2.1.7).

\subsection{Mecanismos específicos para ser implementados por las entidades financieras al momento de hacer entrega de la póliza de seguro de vida grupo deudores.}

Debe partirse que es en la entidad financiera, cuando se materializa la entrega de la póliza de seguro de vida grupo deudores, pues es uno de los requisitos sine qua non que se debe agotar para acceder a un préstamo bancario; luego entonces, es aquí donde se debe hacer mayor énfasis en el deber de información que deben procurar dichas entidades, pues no puede perderse de vista que lo que verdaderamente puede interesar al consumidor financiero, en principio, es que se acceda a su solicitud de préstamo.

Así las cosas, y partiendo que la información que las entidades financieras deben brindar a sus consumidores financieros, debe ser cierta, suficiente, clara y oportuna, que 
permita, especialmente, que aquellos conozcan adecuadamente sus derechos, obligaciones y los costos en las relaciones que establecen, según lo prevé el estatuto del consumidor financiero (Ley 1328, 2009, art. 3), se consideran los siguientes mecanismos para lograr ello:

- Personal suficiente y capacitado, que tenga amplio conocimiento de los derechos (eventos en los cuales sí o no se encuentra cubierto el riesgo que se ampara) y las obligaciones (valor de la prima y modo de pago) que se adquieren con la póliza de seguro de vida grupo deudores. El procedimiento que se sugiere es que dicho personal, haga una breve explicación sobre tales aspectos, utilizando un lenguaje expositivo, en aras de dejar claros todos los aspectos que guardan relación con la póliza. De igual forma, que tomen el tiempo suficiente y necesario para dar respuesta a todas las interrogantes que el consumidor financiero les plantee sobre los derechos y obligaciones que adquirirán en virtud de tal contrato de seguro.

- Líneas de atención, las cuales se pueden implementar, en la medida que la entidad financiera no pueda disponer de personal de manera presencial en sus instalaciones. La persona que atienda esta línea, también deberá estar capacitada, para brindar una información clara y precisa sobre la póliza, y responder todas las interrogantes que le sean planteadas.

- Folletos informativos, en los cuales se indique a través de un lenguaje de fácil comprensión, sin la utilización de tecnicismo, o términos jurídicos propios de las aseguradoras, los derechos y obligaciones que tienen los consumidores financieros que adquieren una póliza de seguro de vida grupo deudores. Este folleto deberá incluir además, las distintas formas en las cuales todos los 
consumidores financieros pueden ejercer sus derechos, con relación a la póliza, cuando se vean auscultados por la entidad financiera.

- Canales virtuales, a través de los cuales las entidades financieras pueden brindar información mediante el servicio de chat con sus asesores, quienes deben estar en capacidad de dar respuesta a todas las interrogantes que tenga el consumidor financiero sobre la póliza que adquirió. De igual forma, en los portales web de cada entidad financiera, los derechos y obligaciones que tienen los consumidores financieros que adquieren una póliza de seguro de vida grupo deudores.

- Encuestas de satisfacción, las cuales permiten evidenciar si el consumidor financiero obtuvo de manera clara y precisa todo lo relacionado con la póliza de seguro de vida grupo deudores que adquirió. De evidenciarse lo contrario, a saber, que el consumidor financiero no obtuvo una información de manera clara y precisa, la entidad financiera deberá ponerse en contacto con este, en procura de brindar nuevamente la información y resolver todas las dudas que se tengan al respecto.

\subsection{Conclusiones}

Primera. El deber de información se convierte en un imperativo de primer orden para la defensa de los derechos del consumidor financiero. Dicho deber recae no sólo en las entidades aseguradoras, sino en cabeza también de la Superintendencia Financiera de Colombia, en tanto al ser el ente encargado de la vigilancia del sector, requiere de medidas eficaces para que la información que llegue al deudor o asegurados sea lo más clara posible, 
máxime que el deudor carece en la mayoría de casos de las competencias para conocer a profundidad los efectos de las cláusulas estipuladas para los seguros de vida grupo deudores.

Ello conlleva en subrayar, dando respuesta a la pregunta de investigación, se puede advertir que el estatuto del consumidor no logra garantizar de forma efectiva los derechos fundamentales de los usuarios de las entidades aseguradoras, sobre todo el deber de información, en los usuarios pertenecientes al seguro de vida grupo deudores. Esta afirmación obedece a que los usuarios no cuentan con otra opción que recurrir a la Corte Constitucional para que les garantice sus derechos fundamentales en este tipo de contratos de adhesión, cuya principal característica es ser contratos leoninos.

Segunda. Dados los evidentes niveles de asimetría entre las partes intervinientes en un contrato de seguro de vida grupo deudores, sobre todo porque se logra visibilizar una falta de ética al momento de suscribir los contratos con las entidades bancarias, ya que al corresponder la aseguradora al mismo grupo empresarial, ello ocasiona un conflicto de interés que está perjudicando notablemente al deudor asegurado.

Tercera. Es indudable la necesidad de que la industria aseguradora establezca o construya un manual de buenas prácticas en contratos de seguro, en el que se apliquen y materialicen las medidas adoptadas por el legislador para la protección de los consumidores financieros. Sin duda, al no desarrollarse un manual ético al interior de esta industria, difícilmente se podrá superar algo de dicha asimetría.

Cuarta. La nueva configuración de los derechos del consumidor, establecida tanto en el Estatuto del Consumidor como la desarrollada en la Ley 1328 de 2009, generan consecuencias en el contrato de seguro establecidas en el Código del Comercio, lo que exige 
que se genere, desde la jurisprudencia, una interpretación integral de forma tal que se contemplen y delimiten derechos para las partes.

Quinta. Se comparte la postura de autores como Maudos y Fernández (2006) en relación con el sistema financiero que, tal como está actualmente operando en Colombia y en el mundo en general, se constituye como un fenómeno que genera una posición dominante hacia los usuarios y clientes. Esto se pone en evidencia no sólo en el ámbito particular del consumidor, sino de las mismas instituciones del Estado, incluyendo los organismos de vigilancia y control de la actividad financiera, que son los encargados de amparar a la parte débil de la negociación: el consumidor.

Sexta. La protección al consumidor se encamina a varios escenarios, entre los cuales son más relevantes entender la correspondencia entre un régimen enérgico de defensa al consumidor y la estabilidad financiera. Así también, en vigorizar las relaciones entre amparo e inserción financiera, y, por último, promover técnicas que ayuden al adelanto de las capacidades financieras de los consumidores.

Séptima. La noción de consumidor financiero que se aplica en la actualidad cubre a cualquier persona que utilice los servicios financieros, así sea mínimamente, con lo cual asume tal condición. Esto implica tener la protección sistemática por parte del Estado frente a las actuaciones de los proveedores de servicios financieros. En ese sentido, para poder lograr una atención eficiente, es un imperativo que las entidades financieras brinden la debida información a sus usuarios, respecto a cada uno de los servicios que prestan, siempre en función que la misma se cierta, clara, oportuna y suficiente. 
Octavo. Colombia cuenta con un marco legal, doctrinal y jurisprudencial suficientemente amplio y consolidado, lo que ha coadyuvado a que se genere una mayor conciencia en los consumidores acerca de sus derechos, pero también ha permitido que los proveedores de servicios financieros fijen su atención en una mejor prestación de dichos servicios, más cuando se cuenta con una entidad como la Superintendencia Financiera, a través de la cual se pueden direccionar las quejas y reclamos y obtener pronta solución.

Noveno. Las peculiaridades de los contratos de seguro de vida grupo deudores, permiten señalar que es un contrato de adhesión, caracterizado por dos entidades financieras con posición dominante, como son los bancos y las aseguradoras, frente al usuario o consumidor financiero, que es el asegurado. Al ser contratos "leoninos", la función de este último se circunscribe únicamente a aceptar los criterios, alcance, cobertura y valor de este tipo de contratos.

\subsection{Referencias}

Acegroup. (2017). Derechos y obligaciones de los consumidores financieros y de las entidades aseguradoras. Recuperado de http://www.acegroup.com/coes/assets/derechos-y-obligaciones-spanish.pdf

AON Corredores de Seguros (2016). Derechos y deberes del consumidor financiero. Recuperado de http://www.aon.com/colombia/attachments/a-flyer-educacionfinanciera-2016.pdf

Arévalo, J. y Rivera, C. D. (2013). Las cláusulas abusivas en el ámbito de la protección al consumidor en Colombia. Bogotá: Pontificia Universidad Javeriana. Facultad de Ciencias Jurídicas.

Recuperado

de 
https://repository.javeriana.edu.co/bitstream/handle/10554/9903/ArevaloLaraJuliana 2013.pdf?sequence $=1$

Ayala, A. I. (2016). Reticencia e inexactitud en el contrato de seguros. Bogotá: Universidad $\begin{array}{llll}\text { Católica } & \text { de } & \text { Colombia. } & \text { Recuperado }\end{array}$ http://repository.ucatolica.edu.co/bitstream/10983/13710/4/RETICENCIA\%20E\%2 OINEXACTITUD\%20EN\%20EL\%20CONTRATO\%20DE\%20SEGUROS.pdf

Barbosa, D., Ramírez, C. y Vargas, M. (2014). Globalización, capitalismo financiero y responsabilidad social empresarial: tensiones estructurales. Revista Civilizar. 14(27), $135-154$.

Barrero, J. F. (2016). El defensor del consumidor financiero como conciliador. Recuperado de http://repository.ucc.edu.co/bitstream/ucc/211/1/El\%20Defensor\%20Consumidro\% $20 \% 20 \% 20$ Financiero\%20\%20UCC\%20\%20Alumno\%20Jhon\%20Barrero\%20correci\%C3\%B3n\%20final\%2 0\%20Febrero\%2011-201.pdf

Bernal, M. M. (2015). La cultura del servicio de las entidades financieras en Colombia: un análisis para incrementar la generación de valor. Bogotá: Universidad Militar Nueva Granada. Facultad de Ciencias Económicas. Recuperado de http://repository.unimilitar.edu.co/bitstream/10654/6624/1/BERNALGOMEZMONI CAMARIA2015.pdf 
Betancourt, G. (2014). Funciones jurisdiccionales de la Superintendencia Financiera de Colombia: análisis desde la regulación de protección al consumidor. Revista Digital de Derecho Administrativo. (12), 141-166.

Blanco, C. (2008). El nuevo esquema de control del mercado financiero - la Superintendencia financiera de Colombia Recuperado de https://www.uexternado.edu.co/wp-content/uploads/2017/01/ConstanzaBlanco$\underline{3 . p d f}$

Blanco, C. (2012). La información como instrumento de protección de los consumidores, los consumidores financieros y los inversionistas financieros. Revista Opin. jurid. 11(21), $135-152$.

Bustos, M. F. (2016). Aproximación a la estructura sistemática del derecho administrativo económico colombiano. Revista Justicia Iuris. 121(1), 27-39.

Cano, C. G., Esguerra M. del P., García, N., Rueda, L. y Velasco, A. M. (2014). Inclusión financiera en Colombia. Bogotá: Banco de la República. Recuperado de http://www.banrep.gov.co/sites/default/files/eventos/archivos/sem_357.pdf

Chamie, J. F. (2013). Principios, derechos y deberes en el derecho colombiano de protección al consumidor. Revista de Derecho Privado. (24). Recuperad de http://revistas.uexternado.edu.co/index.php/derpri/article/view/3481/3467

Chiriboga, L. (2010), Sistema financiero. Quito: autor. 2010. Recuperado de http://repositorio.iaen.edu.ec/handle/24000/2635

Colombia. Corte Constitucional. (2012). Sentencia C-909 (7, noviembre, 2012). M. P. Nilson Pinilla Pinilla. 
Colombia. Corte Constitucional. (2016). Sentencia t-240 (16, mayo, 2016). M. P. Jorge Ignacio Pretelt Chaljub.

Congreso de Colombia. (2009). Ley 1328 (15, julio de 2009). Por la cual se dictan normas en materia financiera, de seguros, del mercado de valores y otras disposiciones.

Congreso de Colombia. (2010). Decreto único 2555 (15, julio, 2010). Por el cual se recogen y reexpiden las normas en materia del sector financiero, asegurador y del mercado de valores y se dictan otras disposiciones.

Congreso de Colombia. (2011). Ley 1480 (12, octubre, 2011). Por medio del cual se expide el Estatuto del Consumidor y se dictan otras disposiciones.

Congreso de Colombia. (2012). Ley 1555 (9, julio, 2012). Por medio del cual se permite a los consumidores financieros el pago anticipado en las operaciones de crédito y se dictan otras disposiciones.

Congreso de Colombia. (2014). Ley 1748 (26, diciembre, 2014). Por medio de la cual se establece la obligación de brindar información transparente a los consumidores de los servicios financieros y se dictan otras disposiciones.

Cuéllar, M. M. (2012). II Congreso de Protección al Consumidor y Educación Financiera. Bogotá: autor.

Daher, A. y Moreno, D. (2016). Crisis financieras y sustentabilidad socioeconómica. Revista Lecturas de Economía. (85), 211-242.

Díaz, J. M. (2012). El nuevo estatuto del consumidor en Colombia. Su incidencia en el contrato de seguro. Revista RIS. 36(21), 59-96. 
Fasecolda. (2014). Informe de sostenibilidad de Fasecolda 2014. Recuperado de

Gaviria, C. (2001). La consensualidad en el contrato de seguro. Bogotá: Pontificia Universidad Javeriana. Facultad de Ciencias Jurídicas. Derecho Privado. Recuperado de http://hermes.javeriana.edu.co/biblos/tesis/derecho/dere2/Tesis23.pdf

Global Seguros Colombia. (2017). Derechos y obligaciones del consumidor financiero de Global Seguros Vida $\quad$ S. $\quad$ A. Recuperado de http://www.globalseguroscolombia.com/wp-content/uploads/2016/09/derechos-yobligaciones-consumidor-financiero.pdf

Gutiérrez, A. (2008). Estructura del sistema financiero. México: Centro de Estudios de las $\begin{array}{llll}\text { Finanzas } & \text { Públicas. } & \text { Recuperado }\end{array}$ https://cuadernosdelprofesor.files.wordpress.com/2017/01/u-1-03-dm$\underline{\text { 06seminariosfm.pdf }}$

Hernández, L. y Parro, F. (2004). Sistema Financiero y crecimiento económico en Chile. Santiago de Chile: Banco Central de Chile. Documentos de Trabajo $N^{\circ} 291$.

Lizama, G. A. (2016). Comportamiento cooperativo y contratos de adhesión. Santiago de Chile: Universidad de Chile. Facultad de Derecho. Recuperado de http://repositorio.uchile.cl/bitstream/handle/2250/140464/Comportamientocooperativo-y-contratos-de-adhesi\%C3\%B3n.pdf?sequence=1

López, J. R. (2008). La controversia del contrato de adhesión. Recuperado de http://www.derecho.uady.mx/tohil/rev21/7_La\%20Controversia\%20del\%20Contrat o\%20de.... 7 .pdf 
López, L. C. y Martelo, V. J. (2012). La protección del consumidor en Colombia en la Ley 1480 de 2011 a partir de las directrices de la Resolución 39/248 de la ONU. Cartagena de Indias: Universidad de Cartagena. Facultad de Derecho y Ciencias Políticas. Programa de Derecho. Recuperado de http://190.242.62.234:8080/jspui/bitstream/11227/831/1/MONOGRAF\%C3\%8DA \%20DE\%20GRADO.pdf

Maudos, J. y Fernández, J. (2006). Desarrollo financiero, dependencia financiera y crecimiento económico sectorial: nueva evidencia internacional. Recuperado de http://www.uv.es/maudosj/publicaciones/Maudos\%20y\%20fernandez_PEE2006.pdf

Medina, C. A. y Vargas, M. S. (2013). Globalización, capitalismo financiero y responsabilidad social empresarial: tensiones estructurales. Bogotá: Universidad del Rosario. Facultad de Administración. Recuperado de http://repository.urosario.edu.co/bitstream/handle/10336/4337/799526132013.pdf? sequence $=3$

Moreno, M. M. (2014). Control de cláusulas abusivas en el contrato de adhesión con el consumidor fiduciario. Revista Univ. Estud. Bogotá. (11), 331-353.

Morgestein, W. I. (2014). El concepto de información en el Estatuto del Consumidor colombiano. Un estudio jurídico de la institución en la Ley 1480 de 2011. Revista Estud. Soci-Jurid. 17 (1), 195-217.

Muñoz, S. H. (2012). El derecho a la información en la esfera de protección al consumidor. Revista Electrónica. Facultad de Derecho y Ciencias Políticas. 8(3), 1-20. 
Namén, J. Bonilla, J., Pabón, C. y Uribe, I. D. (2009). La obligación de información en las diferentes fases de la relación del consumo. Revista e-mercatori@, 8(1), 1-29.

Narváez, J. E. (2014). El contrato de seguro en el sector financiero. $3^{\mathrm{a}}$ ed. Bogotá: Grupo Editorial Ibáñez.

Palacios, F. Ed. (2016). Seguros. Temas esenciales. 4ª ed. Bogotá: Ecoe Ediciones.

Paolantonio, M. (2010a). El derecho del mercado de capitales. Revista Derecho Comercial del Consumidor y de la Empresa. 1 (1), 261-270.

Patiño, P. J. (2012). Nuevo estatuto del consumidor. Protección y garantía de los derechos del consumidor hacia un comercio internacional. Revista Academia Libre. 9(10), 2535.

Pecho, M. (2013). Hechos estilizados de los impuestos sobre las transacciones financieras en América Latina: 1990-2012. Recuperado de http://www.estimacionestributarias.com/archivos/ITF.\%20M\%20Pecho.pdf

Peñalosa, J. Z. (2015). Reflexiones para el sector asegurador colombiano a partir de una minirevisión de literatura sobre la NIIF4. Pontificia Universidad Javeriana. Facultad de Ciencias Económicas. https://repository.javeriana.edu.co/bitstream/handle/10554/16683/PenalosaCardenas JenniferZulay2015.pdf?sequence $=1$

Pinzón, N. M. (2016). De la reticencia en el contrato de seguro: un estudio sobre la inobservancia al principio de la buena fe contractual y sus consecuencias. Recuperado de 
http://repository.ucatolica.edu.co/bitstream/10983/6162/1/DE\%20LA\%20RETICEN CIA\%20EN\%20EL\%20CONTRATO\%20DE\%20SEGURO.pdf

Posada, C. (2015). Las cláusulas abusivas en los contratos de adhesión en el derecho colombiano. Revista de Derecho Privado. (29), 141-182.

Presidencia de Colombia. (1993). Decreto 663 (2, abril, 1993) Por medio del cual se actualiza el Estatuto Orgánico del Sistema Financiero y se modifica su titulación y numeración.

Presidencia de Colombia. (2005). Decreto 4327 (25, noviembre, 2005). Por el cual se fusiona la Superintendencia Bancaria de Colombia en la Superintendencia de Valores y se modifica su estructura.

Quintero, O. (2014). Defensas administrativas y judiciales del consumidor. Del Decreto 3466 de 1982 a la Ley 1480 de 2011. Revista e-mercatoria. 13(1), 91-125.

Saavedra, C. (2012). El deber de información al consumidor financiero: caso de los deudores de créditos hipotecarios en la crisis del 2008. Revista emercatoria. 11(2), 149-175

Superintendencia Financiera de Colombia. (2010). Educación financiera, estadística de quejas, sistema general de pensiones, afiliados y traslados de régimen. Concepto 2010032107-001 (26, junio, 2010).

Superintendencia Financiera de Colombia. (2017). Información estadística - anual.

Recuperado de de https://www.superfinanciera.gov.co/jsp/loader.jsf?1Servicio=Publicaciones\&lTipo= publicaciones\&lFuncion=loadContenidoPublicacion\&id=11129 
Suramericana de Seguros. (2017). Tus deberes y derechos. Recuperado de https://www.sura.com/documentos/atencion-consumidor-financiero/derechosdeberes-consumidor-financiero.pdf

Vásquez, C. (2012). Protección al consumidor financiero. Avances y retos del sector asegurador. Bogotá: $\quad$ Fasecolda. Recuperado de http://www.fasecolda.com/files/9113/9101/2240/parte_ii.captulo_7_proteccin_al_co $\underline{\text { nsumidor_financiero.pdf }}$

Viguria, C. (2013). El consumidor financiero: necesidades de su implementación en el Sistema Nacional de Protección al Consumidor. Lima: Pontificia Universidad Católica del Perú. Facultad de Derecho. Recuperado de http://tesis.pucp.edu.pe/repositorio/handle/123456789/1679

Vilela, J. E. (2012). La protección del consumidor financiero. Recuperado de http://www.itaiusesto.com/wp-content/uploads/2012/12/3_6-Vilela-Carbajal.pdf 


\section{Anexos}

Anexo A. Sentencias hito en seguros de vida grupo deudores

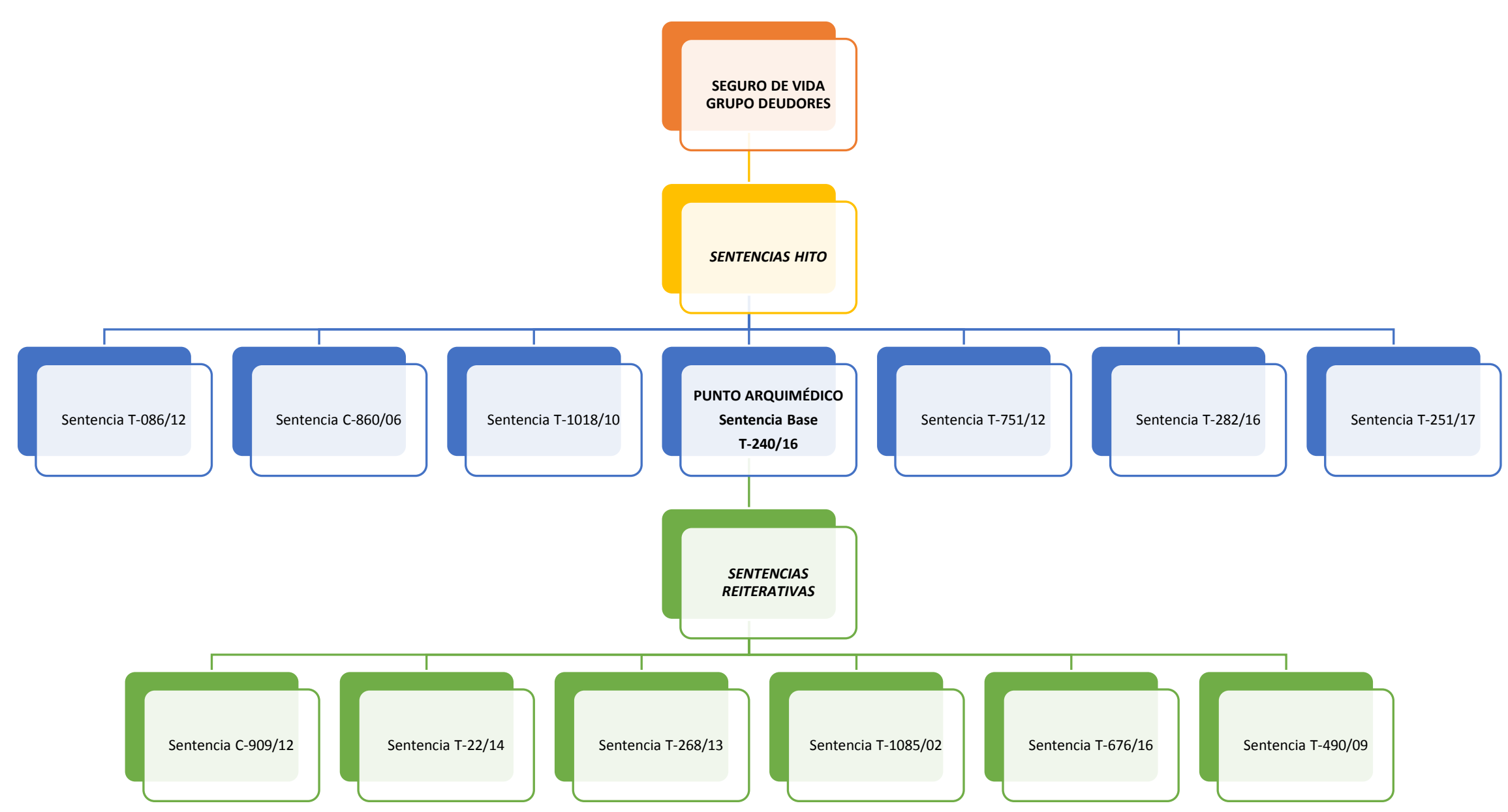

